\title{
The Golden Period FOR GROWTH IN CHILE: ExPlanations AND FoRECASTS
}

\author{
Francisco Gallego \\ Massachusetts Institute of Technology \\ Norman Loayza \\ World Bank
}

Chile registered a remarkable economic growth performance between 1985 and 1998, when the country's growth rate was in the top four worldwide. Equally remarkable is the fact that this high rate resulted from a sharp turnaround in economic growth. In fact, the change in Chile's per capita gross domestic product (GDP) growth rate between 1985-1998 and the previous fifteen years was, by far, the highest in the world. This paper follows a macroeconomic perspective to study Chile's economic growth performance in the last four decades, using regional and world trends as benchmarks for comparison. The first objective of the paper is to consider a series of questions and hypotheses to explain Chile's growth improvement. Explaining economic growth in Chile is important not only for academic reasons, but also because it could shed light on the sustainability of high growth rates in the country. Thus, a second objective of the empirical analysis is to assess what can be expected for Chile's growth rate in the future-and to identify the pre-conditions for continued growth.

Chile's outstanding macroeconomic performance in the late $1980 \mathrm{~s}$ and 1990s has been portrayed as an example of successful marketoriented policies. As such, it has been the subject of numerous studies,

We are grateful to William Easterly, Ross Levine, Klaus Schmidt-Hebbel, and particularly our discussants Rodrigo Fuentes and Andrés Solimano for useful comments. This paper was written while Francisco Gallego was affiliated with the Central Bank of Chile. The opinions and conclusions of this study do not necessarily represent those of the Central Bank of Chile or the World Bank.

Economic Growth: Sources, Trends, and Cycles, edited by Norman Loayza and Raimundo Soto, Santiago, Chile. (c) 2002 Central Bank of Chile. 
including, for instance, Bosworth, Dornbusch and Labán (1994); Corbo, Lüders, and Spiller (1997); Perry and Leipziger (1999); and Solimano (1999). There is a large empirical literature that attempts to explain the determinants of Chile's growth achievement. We classify these articles into four categories, based on their methodology. The first group takes a time-series econometric approach. Examples include Coeymans (1999); Jadresic and Zahler (2000); and Rojas, López, and Jiménez (1997). The second group uses growth accounting to identify the relative contribution of production factors and total factor productivity (TFP). In this group are Chumacero and Fuentes (2001); Corbo, Lüders, and Spiller (1997); De Gregorio (1997); Marfán and Bosworth (1994); Meller, O’Ryan, and Solimano (1996); Roldós (1997); and Contreras and García (2002). The third category uses calibrated analytical models to study economic growth in Chile. Here we find Bergoeing and others (2001); Braun and Braun (1999); and Schmidt-Hebbel (1999). Finally, the fourth category - the one most related to this paper-uses cross-country evidence to study the Chilean experience. The most recent of these papers are Barro (1999); De Gregorio and Lee (2000); and Lefort (1997).

Most studies find that TFP played an important role in the period of high growth and the corresponding improvement over previous periods. The majority of the studies agree that external conditions, such as favorable terms of trade and greater availability of foreign capital, also contributed to the economy's improved growth performance. Some papers point to the beneficial impact of the market-friendly reforms implemented in Chile since the mid-1970s, arguing that these reforms explain the remarkable increase in total factor productivity and that they prepared Chile to make the best of the international conditions it faced. ${ }^{1}$

This paper belongs in the group of cross-country growth studies, which we extend along the following lines. First, we update previous cross-country research by expanding the sample period up to 1998 . Second, we explicitly consider in the regression analysis the periods before and after 1985, which allows for direct evaluation of the factors behind the jump to high growth. Third, we expand the traditional empirical framework to include nonstandard variables that help explain the marked growth improvement in the last 15 years. Fourth, we present a series of stylized facts regarding the pattern, composition, and sources

1. With different emphases, of course. For example while Rojas, López, and Jiménez (1997) and Coeymans (1999) highlight trade openness, Bergoeing and others (2002) stress the role of financial reform and new bankruptcy laws. 
of growth in the country relative to the Latin America region and the world, with an eye to motivating further study of growth in Chile.

Most papers based on cross-country regressions underpredict the Chilean performance during the period of high growth. For example, Barro's (1999) regression model projects a per capita growth rate of 3.4 percent per year in 1985-1995, while the actual rate was 5.0 percent. This underestimation may contaminate future projections if the Chilean residual is a feature of long-run growth, rather than a transitory phenomenon. We study this issue by including an expanded set of growth determinants in our empirical analysis.

Although we still underestimate the growth improvement in the golden period in Chile, our expanded empirical model of cross-country growth is able to explain a large fraction of this improvement (about 73 percent). Apart from the direct effect of the standard growth determinants (better education and health, deeper financial markets, less government-induced distortions, and more favorable international conditions), indicators of the quality of the political system and governance, the comprehensiveness and complementarity of policy reforms, and the availability of public services and infrastructure appear to play important roles. According to our estimates, a country that jointly implements a series of growth-promoting measures (which we call policy complementarities) gains an additional bonus of more than 1 percentage point in its growth rate, even after controlling for the isolated effect of those measures. This factor appears to be important not only in the case of Chile but also in other high-performing countries such as Ireland, Korea, the Netherlands, and Thailand.

Maintaining the high growth rates of the last fifteen years will be challenging for Chile. The strong convergence effect that results from decreasing marginal returns to capital indicates that, ceteris paribus, Chile's growth rate should start to decline. Therefore, an important task is to find new and continuing sources of growth for the country. The last part of the paper initiates the evaluation of possible growth sources by, first, projecting Chile's growth rate for the next ten years under various assumptions and, second, proposing some areas with potentially large returns, including improvements in the quality of schooling, infrastructure, technology adoption, and government efficiency.

The outline of the paper is the following. Section 1 describes the main stylized facts of growth in Chile from four different macroeconomic perspectives. We first review the long-run growth trends in the country, in Latin America, and in the world by decades from the 1960s through the 1990s. We then examine the sectoral composition of growth 
in Chile to determine the extent of its structural transformation. Next, we carry out a decomposition of growth in Chile into its sources related to capital accumulation, expansion of the labor force, and total factor productivity growth. Finally, we study the dynamic relationship between saving, investment, and growth, using a vector autoregression (VAR) methodology applied previously by Attanasio, Picci, and Scorcu (2000) in a cross-country panel setting.

In section 2 , we attempt to explain the economic growth performance in Chile from a cross-country perspective. We follow the approach in Barro and Lee (1994) and Easterly, Loayza, and Montiel (1997), which consists of linking aggregate economic, political, and social variables to growth rates in per capita GDP for a large sample of countries. The estimated model is then used to forecast changes in the growth rate in the country and examine whether its growth performance has been close to expected values. Since our basic model is not able to fully account for the change of the growth rate in Chile, we then extend the model to incorporate a group of variables recently proposed in the endogenous growth literature.

Section 3 presents some projections for Chile's future growth based on the cross-country empirical results and using a variety of assumptions. In this connection, we also start an evaluation of further sources for growth in the country. Section 4 concludes.

\section{Stylized Facts}

This section describes the main characteristics of economic growth in Chile over the last four decades. We first review the long-run growth trends in the country and the world. We then examine the sectoral composition of growth in Chile and conduct an analysis of the sources of growth via Solow growth accounting. Finally, we study the dynamic relationship between saving, investment, and growth, using vector autoregressions.

\subsection{Long-Run Growth Trends in Chile, Latin America, and the World}

Figure 1 presents the real per capita GDP growth rate in Chile before and after 1985. For comparison purposes, it also presents the growth rates of the median countries in Latin America and the Caribbean and the world, respectively. While Chile lagged behind the typical countries in these groups in 1961-1985, its growth rate of per capita 
Figure 1. Economic Growth in Chile, Latin America and the Caribbean, and the World, 1961-99

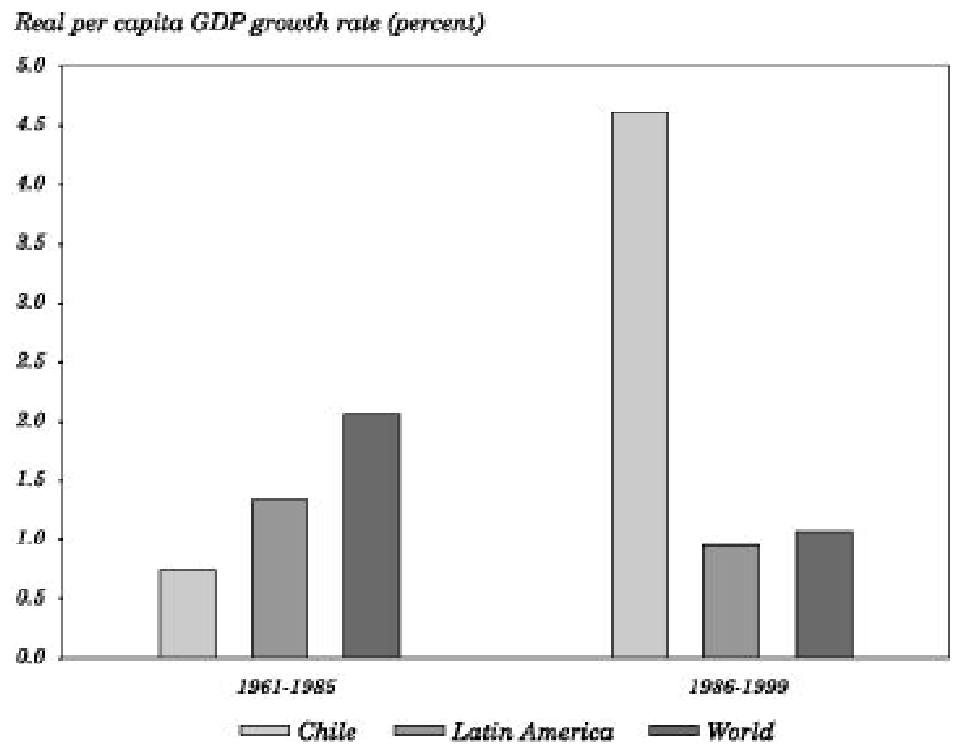

GDP soared to above 4.5 percent in 1986-1999, far surpassing the regional and world medians. Of course, Chile experienced periods of high growth prior to 1985, most notably between 1976 and 1981. Such periods were usually short-lived, however, and they were preceded and followed by sharp recessions. The golden period for growth in Chile is remarkable for its extension and stability.

In contrast to other Latin American countries, the 1980s was not a lost decade for Chile. Even though Chile's GDP fell drastically in the aftermath of the regional debt crisis and its own banking crisis, it fully recovered in the second half of the 1980s and continued to grow throughout most of the 1990s. Not only did Chile experience high growth rates, on average, after 1985, but the volatility of its growth rate was small compared with a worldwide sample of countries (see figure 2 ). ${ }^{2}$

Chile experienced a slowdown in 1998, after thirteen years of sustained high growth rates. While it is uncertain whether this represents a decrease in Chile's trend growth or a prolonged cyclical downturn,

2. The line in figure 2 demonstrates that higher growth is negatively correlated with the variability of growth rates. This point is analyzed in more detail in Fatás (this volume). 
Figure 2. Average Level and Variability of the Growth Rate, 1986-1999

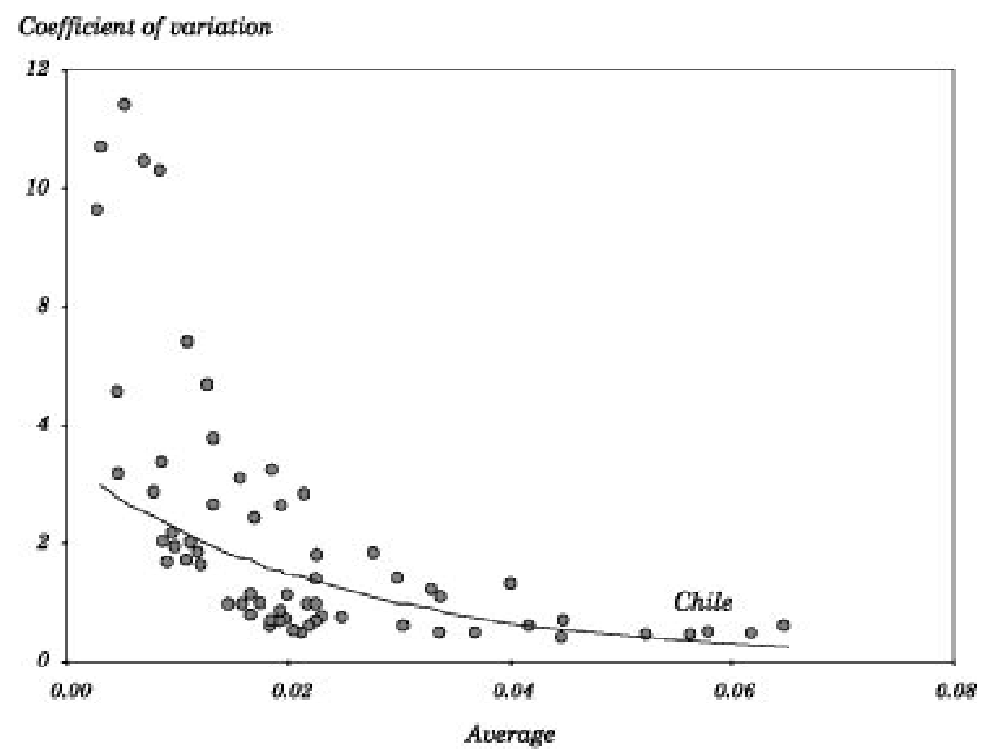

Chile's growth prospects for the future continue to lead the Latin America region and most emerging countries.

The increase in Chile's growth rate-not only in terms of its past performance, but also in comparison with other countries-is an important stylized fact, and as such, it must be analyzed. We do this in section 2 , where we take a cross-country-regression approach to explain the changes in growth rates before and after 1985. For this, we consider the effect of various domestic and international conditions, whether policy determined or not.

\subsection{Sectoral Composition of Output Growth}

Table 1 presents the average output growth rates of primary, industry, and service sectors before and after 1985 in Chile. We also present growth rates by further disaggregated sectors. The increase in the growth rate after 1985 is a phenomenon shared by all major productive areas of the economy. In fact, the primary, industry, and service sectors have more than doubled their growth rates in the last fifteen years (see figure 3 ). 
Table 1. Sectoral Output Growth in Chile, 1961-2000 Percent

\begin{tabular}{|c|c|c|c|}
\hline Sector & $1961-2000$ & $1961-1985$ & $1986-2000$ \\
\hline Primary & 4.1 & 2.8 & 6.2 \\
\hline Agriculture and livestock & 3.2 & 2.0 & 5.1 \\
\hline Fishing & 8.0 & 6.8 & 10.0 \\
\hline Mining and quarrying & 4.4 & 3.2 & 6.3 \\
\hline Industry & 3.5 & 2.2 & 5.6 \\
\hline Manufacturing & 3.4 & 2.3 & 5.3 \\
\hline Construction & 5.5 & 4.9 & 6.5 \\
\hline Gas, electricity, and water & 3.0 & 1.0 & 6.4 \\
\hline Services & 4.2 & 3.0 & 6.2 \\
\hline Wholesale and retail trade & 4.3 & 2.3 & 7.8 \\
\hline Transport and communications & 5.8 & 3.7 & 9.5 \\
\hline Banking & 7.1 & 6.8 & 7.6 \\
\hline Public administration & 2.3 & 1.6 & 3.5 \\
\hline Other services & 2.3 & 2.5 & 1.9 \\
\hline GDP & 4.1 & 2.5 & 6.6 \\
\hline Sectoral dispersion of growth rates ${ }^{\mathrm{a}}$ & 0.43 & 0.59 & 0.38 \\
\hline
\end{tabular}

Source: Central Bank of Chile (2001).

a. The sectoral dispersion of growth rates is measured as the coefficient of variation of the sectoral growth rates in each period.

Among the disaggregated sectors, the growth jump is particularly noticeable in the areas directly affected by the privatization of public enterprises, namely, the utilities (gas, electricity, and water) and transport and communications. However, other sectors also achieved remarkable growth. For example, banking, commerce, and construction grew by more than 6 percent per year after 1985, as did the primary activities of fishing and mining. In addition, the dispersion of growth rates by sectors declined with respect to the previous period.

Contrary to the experience of other developing countries, the primary sector in Chile did not shrink as the economy grew. In fact, in the last forty years, industry lagged behind the other sectors, albeit by a small margin. This produced a slight gain in the primary and service shares of value added at the expense of industry (see figure 4). All in all, however, economic growth in Chile has been balanced across most productive sectors, particularly in the period of high growth after 1985. This suggests that the Chilean economy is internally integrated and diversified, despite its small size. 
Figure 3. Sectoral Economic Growth in Chile, 1961-2000

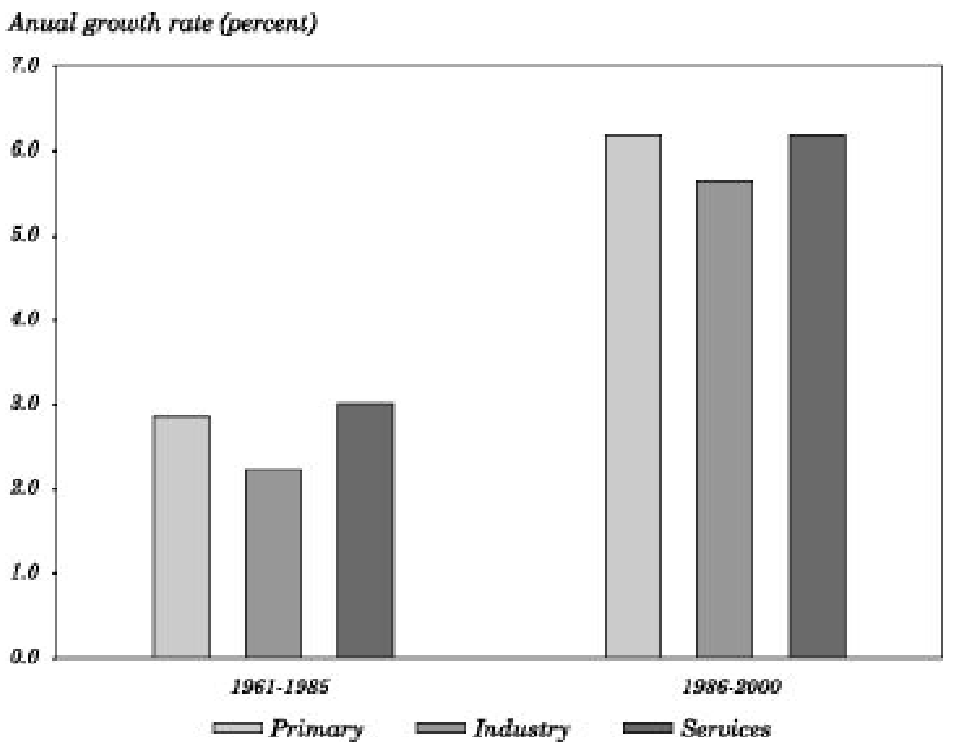

Figure 4. Composition of Chile's GDP by Sector, 1960-2000

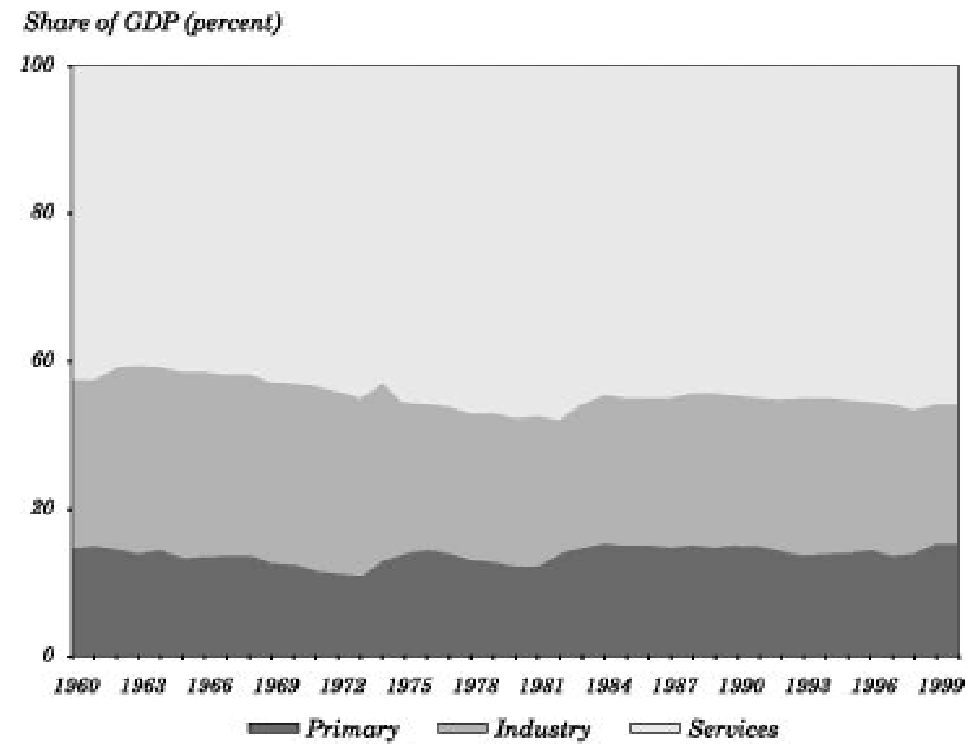




\subsection{Growth Accounting and Trends in TFP}

The next stylized fact stems from a Solow-style decomposition of output growth into the contributions of capital, labor, and productivity growth. We use two methods to derive the Solow decomposition. In both, the contribution of total factor productivity is obtained as a residual once the contributions of capital and labor on output growth are imputed. The difference between the two methods is that the second adjusts for the utilization of capital and labor and adds human capital as a factor of production.

Consider a neoclassical production function that depends on physical capital, $K$; labor, $L$; and the level of total factor productivity, $A$. Assuming, for simplicity, a Cobb-Douglas production function, we have

$Y=A K^{\alpha} L^{1-\alpha}$.

To solve for the growth rate of productivity, we take logs and time derivatives. We follow the international study by Bernanke and Gurkaynak (2001) and the study on Chile by Coeymans (1999) in assuming a capital share $(\alpha)$ of 0.4 . This yields our first Solow decomposition,

TFP1 $=$ GDPGROWTH $-0.4 *$ CAPGROWTH $-0.6 *$ LABORGROWTH,

in which capital growth consists simply of investment net of depreciation, and labor growth comprises only the expansion of the working-age population.

Our second Solow decomposition involves two adjustments. First, we incorporate human capital as a factor of production, $H$, in the aggregate production function. Second, we control for the rate of utilization or employment of capital and labor. Following Bernanke and Gurkaynak (2001), we consider the following human-capital-augmented variation of the previous production function:

$Y=A K^{\alpha}(H L)^{1-\alpha}$,

where $H$ is an index of the quality of the labor force, based on its educational attainment. Following Collins and Bosworth (1996) and Bernanke and Gurkaynak (2001), for each country $i$ we construct $H_{i}$ as a weighted average of the population shares, $E_{i j}$, that attained educational level $j$.

$$
H_{i}=\sum_{j} W_{j} E_{i j}
$$


The weights $W_{j}$ are based on the social returns to schooling for each educational level. Our estimates for $W_{j}$ are based on Psacharopoulos (1994) for the primary, secondary, and tertiary levels of education. The data on educational attainment are from Barro and Lee (2000).

Next, we control for the extent of capital and labor employment. We adjust for the degree of capacity utilization of the capital stock by using, as a proxy, the rate of labor employment. With regard to labor, we adjust for employment by deducting from the working-age population the number of inactive and unemployed people and adjusting for the number of hours actually worked (from the Occupation and Employment Surveys carried out by the University of Chile for 1960-2000).

As before, we assume that $\alpha=0.4$. We then solve for the second measure of growth in TFP (TFP2):

TFP2 $=$ GDPGROWTH $-0.4 *$ CAPGROWTHADJ -0.6 * (LABORGROWTHADJ + HUMCAPGROWTH),

where CAPGROWTHADJ is the utilization-adjusted growth rate of physical capital, LABORGROWTHADJ is the employment-adjusted growth rate of labor, and HUMCAPGROWTH is the growth rate of the human capital index.

Table 2 presents the growth accounting results. The main purpose of the table is to show the differences in the sources of growth for the periods before and after 1985. Similarly, panels A and B of figure 5 present, respectively, the simple and the adjusted growth decompositions before and after 1985 .

According to the simple decomposition, the increase in the GDP growth rate after 1985 was due primarily to a very large expansion of total factor productivity and secondarily to an increase in the contribution of physical capital. Whereas total factor productivity was barely a source of growth in the period 1961-1985, it became the dominant source in 1986-2000. Before 1985 labor was the most important factor behind economic growth in Chile, but its contribution fell in the more recent period in both absolute and relative terms.

Adjusting for human capital and employment considerably increases the contribution of labor to growth, particularly in the period after 1985. The working-age population increased less after 1985 than in the previous period; however, the strong increase in the employment rate and human capital after 1985 more than compensated for the weaker popula- 
Table 2. Growth Accounting in Chile, 1961-2000

Percent

\begin{tabular}{|c|c|c|c|c|c|}
\hline \multirow[b]{2}{*}{ Decomposition and period } & \multirow[b]{2}{*}{ Output } & \multirow[b]{2}{*}{ Physical capital } & \multirow[b]{2}{*}{ Labor } & \multicolumn{2}{|c|}{ Total factor productivity ${ }^{a}$} \\
\hline & & & & TFP1 & TFP2 \\
\hline \multicolumn{6}{|l|}{ Traditional Solow residual } \\
\hline \multicolumn{6}{|l|}{ Annual growth rates } \\
\hline 1961-1985 & 2.54 & 2.68 & 2.34 & - & - \\
\hline $1986-2000$ & 6.64 & 6.02 & 1.74 & - & - \\
\hline \multicolumn{6}{|l|}{ Contribution to output growth } \\
\hline 1961-1985 & 2.54 & 1.07 & 1.40 & 0.07 & - \\
\hline $1986-2000$ & 6.64 & 2.41 & 1.04 & 3.19 & - \\
\hline \multicolumn{6}{|c|}{ Solow residual with adjustments for input utilization and human capital } \\
\hline \multicolumn{6}{|c|}{ Annual growth rates } \\
\hline 1961-1985 & 2.54 & 2.38 & 2.95 & - & - \\
\hline $1986-2000$ & 6.64 & 6.16 & 3.70 & - & - \\
\hline \multicolumn{6}{|l|}{ Contribution to output growth } \\
\hline 1961-1985 & 2.54 & 0.95 & 1.77 & - & -0.18 \\
\hline $1986-2000$ & 6.64 & 2.46 & 2.22 & - & 1.95 \\
\hline
\end{tabular}

a. TFP1 = Solow residual TFP2 = Solow residual after controlling for input utilization and human capital .

tion increase. ${ }^{3}$ Likewise, the adjustment for capacity utilization raises the contribution of physical capital in the second period, but only slightly. After 1985 the stock of physical capital (particularly machinery and equipment) grew by more than 6 percent a year, and the rate of capital utilization expanded (rather than shrank, as happened before 1985). Correspondingly, the contribution of total factor productivity after 1985 appears to be more modest when the adjustments are taken into account than otherwise. Indeed, the three sources of growth appear to contribute similar shares after 1985. Even so, while the contribution of labor and, specially, physical capital expanded considerably from the first to the second period, the contribution of total factor productivity increased the most after 1985.

The main conclusion emerging from the growth accounting exercise is that the large increase in the growth rate between 1961-1985 and 1985-2000 was due primarily to an expansion of total factor

3. Improvements in input utilization and human capital from 1961-1985 to $1986-2000$ are seen in the growth rates of physical capital utilization $(-0.29$ versus 0.14 ); the human-capital index ( 0.20 to 0.81 ); employment (1.59 versus 3.08 ); and hours worked $(-0.19$ versus -0.07$)$. The unemployment rate also underwent an important change, as it increased by 7.04 percentage points in the earlier period and decreased by 1.77 percentage points in the later one. 
Figure 5. Growth Accounting in Chile, 1961-2000

A. Solow residual

Percent

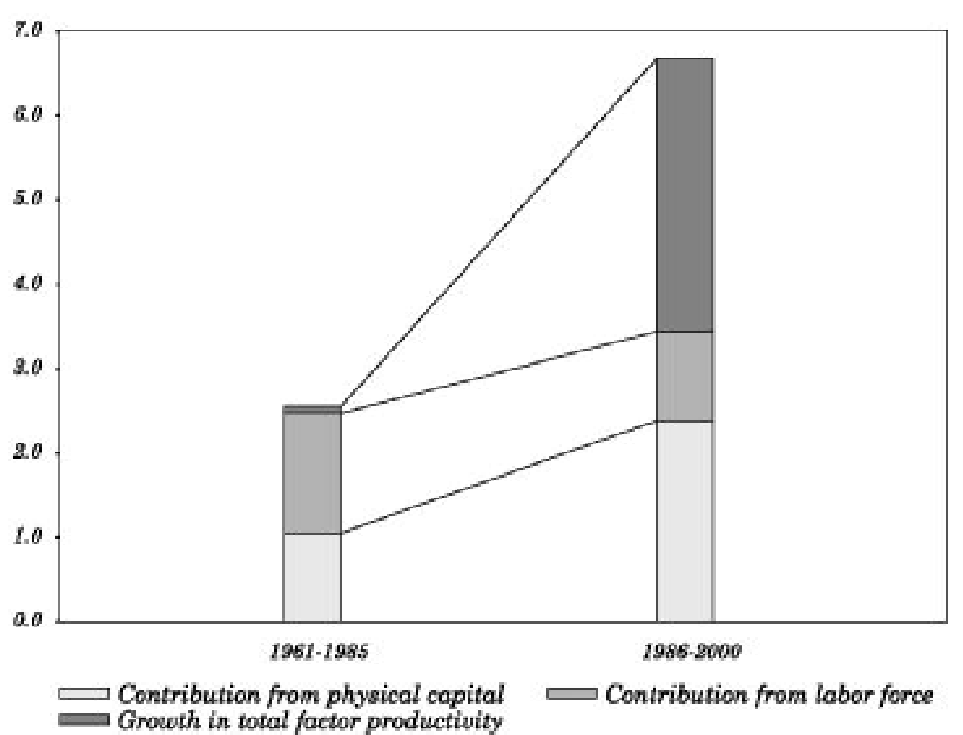

B. Adjusted Solow residual

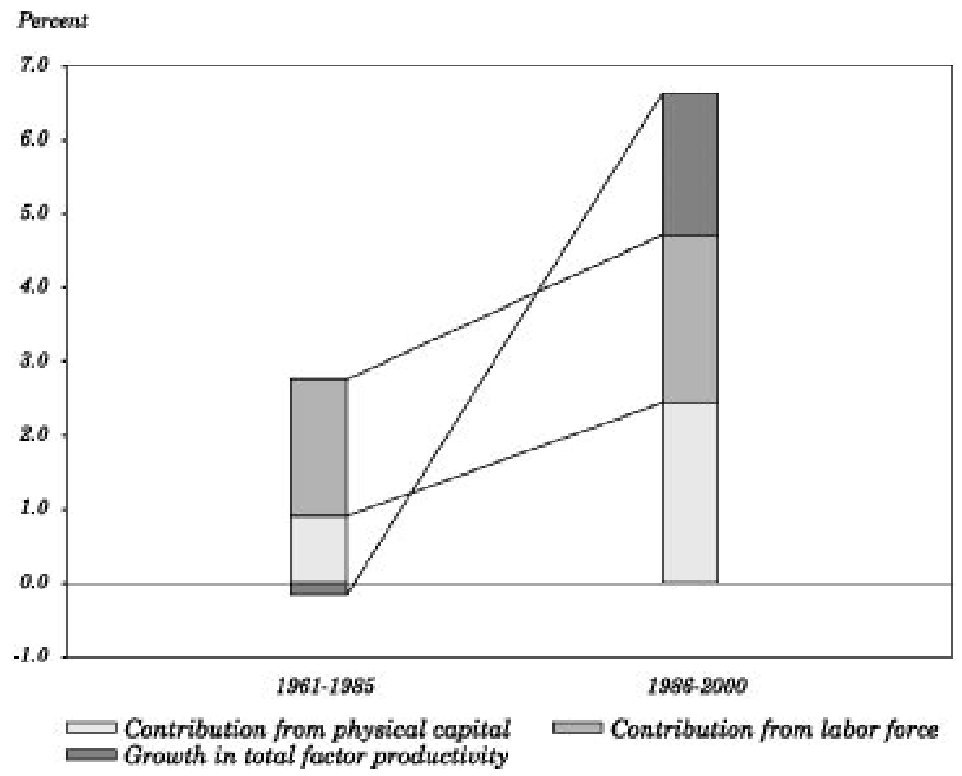


productivity. Before rejecting capital fundamentalism altogether, however, we should highlight the second conclusion-namely, that after 1985, labor, capital, and TFP provide a balanced contribution as sources of growth in Chile. Physical capital, human capital, and the labor force are still the predominant factors accounting for growth in the country.

\subsection{Growth, Saving, and Investment}

We now explore the dynamic relationship between the growth rate and the saving and investment ratios. Following Attanasio, Picci, and Scorcu (2000), we study these relationships by running VAR systems on annual data. We consider three bivariate systems, namely, investment and growth; national saving and growth; and external saving and growth. The VARs include one lag of each variable ${ }^{4}$

Table 3 presents the results. The dynamic relationship between investment and growth at annual frequencies reveals that investment has a high degree of inertia and is significantly predicted by past growth. The latter result can be explained by considering that past growth creates incentives to new investment by making future growth more likely. Growth also exhibits some inertia, but surprisingly, it is not significantly predicted by past investment. Judging only by the sign of the coefficient, lagged investment appears to have a negative link with growth. This result may seem to contradict the cross-country evidence, which finds a positive effect of investment on growth. The two results are not necessarily contradictory, however, given that the dynamic relationship estimated here considers effects over relatively short horizons (a few years) while the cross-country analysis focuses on long periods. Attanasio, Picci, and Scorcu (2000) and Blomstrom, Lipsey, and Zejan (1996) find a negative (short-run) link between past investment and current growth. They offer two explanations for this result: either investment is limited by saving, which anticipates growth negatively, or growth behaves cyclically, with high growth and investment preceding low growth.

The dynamic relationship between national saving and growth in Chile is not significant at short horizons according to our estimated VARs. Both saving and growth are predicted by their respective past values, and the degree of inertia is higher in the case of saving. It is surprising that growth does not Granger-cause saving and vice versa,

4. Further lags do not enter significantly in the regressions and are thus excluded in the final estimated system. 
Table 3. Investment, Domestic and Foreign Saving, and Growth in Chile ${ }^{a}$

\begin{tabular}{|c|c|c|c|c|c|c|}
\hline \multirow[b]{2}{*}{ Explanatory variable } & \multicolumn{2}{|c|}{$V A R(1)$} & \multicolumn{2}{|c|}{$V A R(2)$} & \multicolumn{2}{|c|}{$V A R(3)$} \\
\hline & Investment & Growth & $\begin{array}{l}\text { Domestic } \\
\text { saving }\end{array}$ & Growth & $\begin{array}{l}\text { Foreign } \\
\text { saving }\end{array}$ & Growth \\
\hline Growth (-1) & $\begin{array}{l}0.1580 * * \\
(0.0730)\end{array}$ & $\begin{array}{r}0.3302 * \\
(0.1724)\end{array}$ & $\begin{array}{l}-0.1200 \\
(0.1553)\end{array}$ & $\begin{array}{r}0.3113^{*} \\
(0.1789)\end{array}$ & $\begin{array}{l}0.2525^{* *} \\
(0.1124)\end{array}$ & $\begin{array}{r}0.3058 * \\
(0.1630)\end{array}$ \\
\hline Investment (-1) & $\begin{array}{l}0.8269^{* *} \\
(0.0808)\end{array}$ & $\begin{array}{l}-0.0359 \\
(0.1908)\end{array}$ & & & & \\
\hline Saving $(-1)$ & & & $\begin{array}{l}0.7747 * * \\
(0.1287)\end{array}$ & $\begin{array}{c}0.0105 \\
(0.1482)\end{array}$ & & \\
\hline Foreign saving $(-1)$ & & & & & $\begin{array}{l}0.5573^{* *} \\
(0.1350)\end{array}$ & $\begin{array}{l}-0.0563 \\
(0.1958)\end{array}$ \\
\hline $\begin{array}{l}\text { Summary statistics } \\
R^{2} \\
\text { No. observations }\end{array}$ & $\begin{array}{c}0.8076 \\
39\end{array}$ & $\begin{array}{c}0.1013 \\
39\end{array}$ & $\begin{array}{c}0.5359 \\
39\end{array}$ & $\begin{array}{c}0.1005 \\
39\end{array}$ & $\begin{array}{c}0.3416 \\
39\end{array}$ & $\begin{array}{c}0.1025 \\
39\end{array}$ \\
\hline
\end{tabular}

* Significant at the 10 percent level.

*** Significant at the 5 percent level.

a. VAR estimations, using annual data for 1961-2000. Savings and investment expressed as ratios to GDP. Growth rate is the real per capita GDP growth rate. Standard errors are in parentheses.

although Gallego, Morandé, and Soto (2001) find a similar result for Chile. This may indicate that cyclical effects are transmitted within the same year or that long-run relationships take horizons of substantially more than a few years to materialize (especially in a context of underdeveloped financial markets, as was the case in Chile until the 1990s).

The dynamic relationship between foreign saving and growth is more interesting. Again, both variables show significant inertia, which is higher in the case of foreign saving. Whereas foreign saving does not help predict economic growth, an increase in growth is significantly associated with a rise in foreign saving. While this result is not inconsistent with a long-run positive effect of foreign saving on domestic growth, it does indicate that in short horizons, international capital flows are driven by higher domestic returns, rather than the other way around.

The conclusion that we draw from the dynamic analysis at annual frequencies is that output growth is not Granger-caused by investment, national saving, or foreign saving, although it helps predict investment and foreign saving.

To summarize, the main stylized facts on growth in Chile are, first, that the rate of output growth became significantly higher and more stable after 1985 than in the past; second, that this high growth was not limited to a few sectors, but was shared by most of the economy; third, that the jump in economic growth after 1985 reflected mostly a 
large and new improvement in total factor productivity; and fourth, that changes in output growth are not preceded by changes in investment, national saving, or foreign saving. Taken together, these stylized facts suggest that the jump in growth that occurred in Chile after 1985 was driven by policies and macroeconomic conditions that affected the economy's overall productivity.

\section{Determinants of Growth}

This section uses cross-country comparative analysis to identify and quantify the factors behind Chile's growth improvement. We follow the approach in Barro and Lee (1994) and Easterly, Loayza, and Montiel (1997), which consists of linking aggregate economic, political, and social variables to growth rates in per capita GDP for a large sample of countries. The estimated model is then used to project the change of the growth rate in the country and examine whether its performance has been close to expected values.

The regression equation to be estimated is the following:

$y_{i t}-y_{i t-1}=\alpha y_{i t-1}+\beta^{\prime} X_{i t}+\mu_{t}+\eta_{i}+\varepsilon_{i t}$,

where $y$ is (log of ) per capita output, $X$ is a set variables postulated as growth determinants, $\mu_{t}$ is a period-specific effect, and $\eta_{i}$ represents unobserved country-specific factors, and $\varepsilon$ is the regression residual. The subscripts $i$ and $t$ refer to country and time period, respectively.

The sample consists of a balanced panel of forty-six countries for three periods over the years 1960-1998. To smooth out transitory fluctuations, we work with averages and use periods of longer than a decade, specifically, 1960-1970, 1971-1985, 1986-1998. This partition allows us to compare growth before and after 1985, while maintaining the minimum number of consecutive observations per country (that is, three periods) required to run the instrumental variable procedure outlined below. Our sample is determined by the availability of data on relevant variables, and not by arbitrary selection. It includes twenty-two developed and twenty-four developing countries (see appendix A for a complete list). Latin America and the Caribbean is overrepresented in the sample.

The growth regression specified in equation 1 is dynamic, in the sense that it can be rewritten as a lagged dependent variable model. The inclusion of the initial level of per capita output, $y_{i t-1}$, follows from the neoclassical growth model and captures the transitional convergence 
effect. ${ }^{5}$ The time-specific effect, $\mu_{t}$, allows us to control for international conditions that change over time and affect the growth performance of countries in the sample. The term $\eta_{i}$ accounts for unobserved countryspecific factors that both drive growth and are potentially correlated with the explanatory variables.

There is a large variety of economic and social variables that can be proposed as growth determinants, $X$. We use the variables that are most popular in the empirical growth literature given both their quality as indicators of development in specific areas and their data availability. The list of explanatory variables is as follows (see appendix B for details on definitions and sources):

-Initial level of per capita GDP, to capture transitional convergence;

- The initial average years of schooling of the adult population, to proxy for human capital in the working force;

- Life expectancy, to proxy for human capital;

- The ratio of domestic credit in the private sector to GDP, to measure financial development;

- The ratio of the trade volume (real imports plus exports) to real GDP, to measure trade orientation and dependence on international markets;

- The ratio of government consumption to GDP, to measure the burden of government size and taxation on private activity;

- The black market premium on foreign exchange, to proxy for relative price distortions and government intervention in external markets; and

- Terms-of-trade shocks, to account for the effect of international conditions on the country's trade markets.

These variables make up our basic regression model. Figure 6 shows the values of the explanatory variables in the basic model for Chile and the typical (median) country in the world before and after 1985. The basic regression cannot fully explain the change in Chile's growth rate before and after 1985 . We thus augment the model by including variables related to the political system, public infrastructure, and policy complementarities. Figure 7 shows the values of these additional explanatory variables for Chile and the world median over the periods in question.

The proposed growth regression poses a couple of challenges for estimation. The first is the presence of unobserved period- and countryspecific effects. While the inclusion of period-specific dummy variables

5. Transitional convergence is also possible within endogenous growth models; see Turnovsky (2000) for a review. 
Figure 6. Basic Growth Determinants. 1971-1985 versus 1986-1998

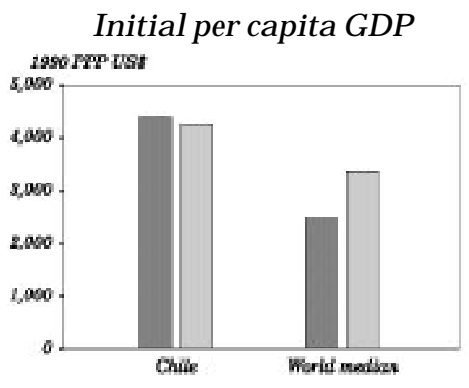

Initial years of schooling

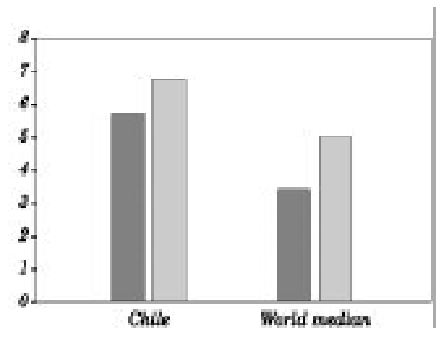

Life expectancy

Domestic credit to private sector
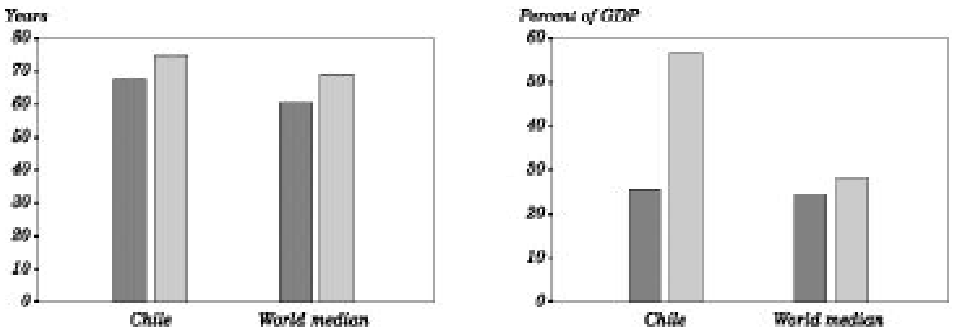

Government consumption

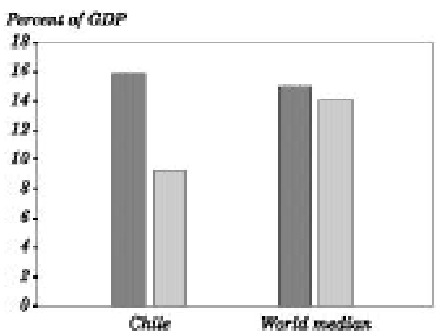

Black market premium

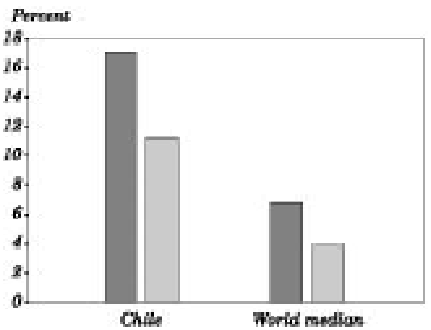

Openness

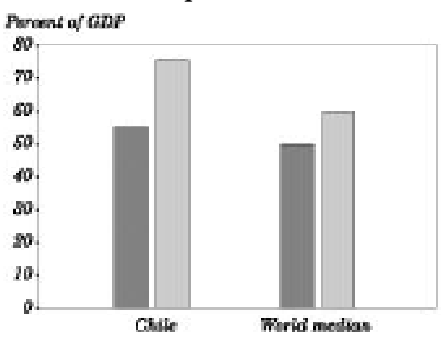

Terms-of-trade growth

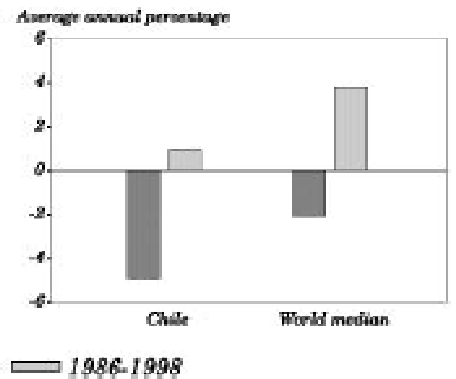


Figure 7. Additional Growth Determinants, 1971-1985 versus 1986-1998

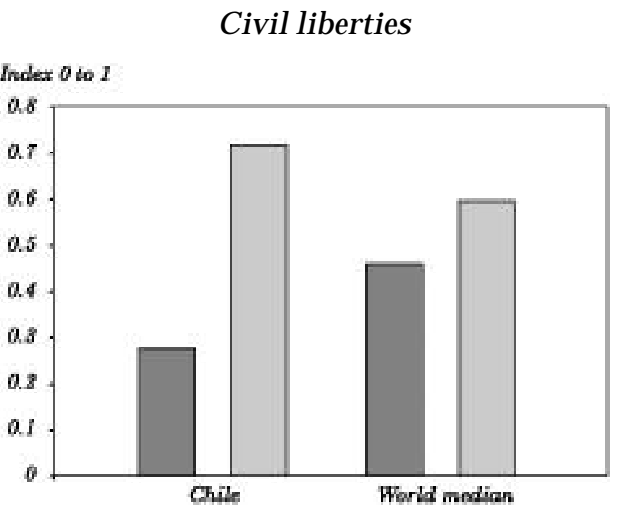

Main telephone lines

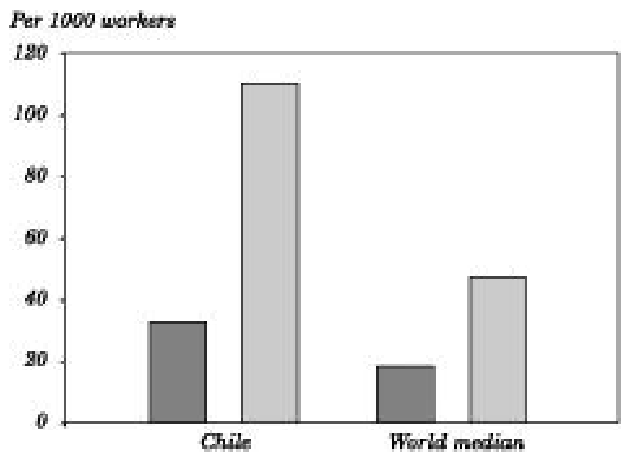

Policy complementarities

Dhummy oor $I$ inder

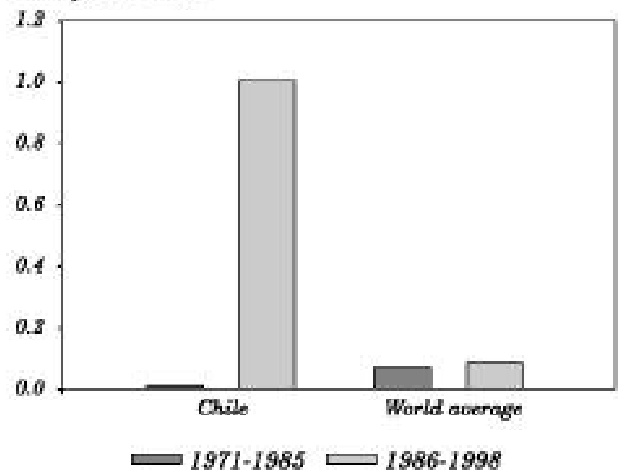


can account for the time effects, the common methods of dealing with country-specific effects ("within" or differences estimators) are inappropriate given the dynamic nature of the regression. The second challenge is that most explanatory variables are likely to be jointly endogenous with economic growth. That is, we need to control for the biases resulting from simultaneous or reverse causation. In the following paragraphs we outline the econometric methodology we use to control for country-specific effects and joint endogeneity in a dynamic model of panel data.

\subsection{Econometric Methodology}

We use the generalized method of moments (GMM) estimators developed for dynamic models of panel data that were introduced by Holtz-Eakin, Newey, and Rosen (1990), Arellano and Bond (1991), and Arellano and Bover (1995). Taking advantage of the data's panel nature, these estimators are based on, first, differencing regressions or instruments to control for unobserved effects (or both), and, second, the use of previous observations of the explanatory variables as instruments (called internal instruments).

After accounting for the time-specific effects, we can rewrite equation 1 as follows:

$y_{i t}=\alpha y_{i t-1}+\beta^{\prime} X_{i t}+\eta_{i}+\varepsilon_{i t}$.

We then eliminate the country-specific effect by taking first-differences of equation 2 :

$y_{i t}-y_{i t-1}=\alpha\left(y_{i t-1}-y_{i t-2}\right)+\beta^{\prime}\left(X_{i t}-X_{i t-1}\right)+\left(\varepsilon_{i t}-\varepsilon_{i t-1}\right)$.

The use of instruments is required to deal with both the likely endogeneity of the explanatory variables and the problem that, by construction, the new error term, $\varepsilon_{i t}-\varepsilon_{i t-1}$, is correlated with the lagged dependent variable, $y_{i t-1}-y_{i t-2}$. The instruments consist of previous observations of the explanatory and lagged dependent variables. Given that it relies on past values as instruments, this method only allows current and future values of the explanatory variables to be affected by the error term. Therefore, while relaxing the common assumption of strict exogeneity, our instrumental-variable method does not allow the $X$ variables to be fully endogenous. 
Under the assumptions that the error term, $\varepsilon$, is not serially correlated and that the explanatory variables, $X$, are weakly exogenous (that is, the explanatory variables are assumed to be uncorrelated with future realizations of the error term), the GMM dynamic panel estimator uses the following moment conditions:

$E\left[y_{i t-s} \cdot\left(\varepsilon_{i t}-\varepsilon_{i t-1}\right)\right]=0$ for $s \geq 2 ; \mathrm{t}=3, \ldots, \mathrm{T}$ and

$E\left[X_{i t-s} \cdot\left(\varepsilon_{i t}-\varepsilon_{i t-1}\right)\right]=0$ for $s \geq 2 ; t=3, \ldots, T$.

The GMM estimator based on these conditions is known as the difference estimator. Notwithstanding its advantages with respect to simpler panel data estimators, the difference estimator has important statistical shortcomings. Alonso-Borrego and Arellano (1996) and Blundell and Bond (1997) show that when the explanatory variables are persistent over time, lagged levels of these variables are weak instruments for the regression equation in differences. Instrument weakness influences the asymptotic and small-sample performance of the difference estimator. Asymptotically, the variance of the coefficients rises. In small samples, Monte Carlo experiments show that the weakness of the instruments can produce biased coefficients ${ }^{6}$

To reduce the potential biases and imprecision associated with the usual difference estimator, we use a new estimator that combines in a system the regression in differences with the regression in levels (developed in Arellano and Bover, 1995; Blundell and Bond, 1997). The instruments for the regression in differences are the same as above; the instruments for the regression in levels are the lagged differences of the corresponding variables. These are appropriate instruments under the following additional assumption: although the levels of the righthand-side variables may be correlated with the country-specific effect in equation 2 , there is no correlation between the differences of these variables and the country-specific effect. This assumption results from the following stationarity property:

$E\left[y_{i t+p} \cdot \eta_{i}\right]=E\left[y_{i t+q} \cdot \eta_{i}\right]$ and

6. An additional problem with the simple difference estimator relates to measurement error: differencing may exacerbate the bias stemming from errors in variables by decreasing the signal-to-noise ratio (see Griliches and Hausman, 1986). 
$E\left[X_{i t+p} \cdot \eta_{i}\right]=E\left[X_{i t+q} \cdot \eta_{i}\right]$ for all $p$ and $q$.

The additional moment conditions for the second part of the system (the regression in levels) are $^{7}$

$E\left[\left(y_{i t-1}-y_{i t-2}\right) \cdot\left(\eta_{i}+\varepsilon_{i t}\right)\right]=0$ and

$E\left[\left(X_{i t-1}-X_{i t-2}\right) \cdot\left(\eta_{i}+\varepsilon_{i t}\right)\right]=0$

We use the moment conditions presented in equations $4,5,7$, and 8 to employ a GMM procedure to generate consistent estimates of the parameters of interest and their asymptotic variance-covariance (Arellano and Bond, 1991; Arellano and Bover, 1995). These are given by the following formulas:

$\hat{\theta}=\left(\overline{\mathbf{X}}^{\prime} \mathbf{Z} \hat{\Omega}^{-1} \mathbf{Z} \overline{\mathbf{X}}\right)^{-1} \overline{\mathbf{X}}^{\prime} \mathbf{Z} \hat{\Omega}^{-1} \mathbf{Z}^{\prime} \overline{\mathbf{y}}$ and

$\operatorname{avar}(\hat{\theta})=\left(\overline{\mathbf{X}}^{\prime} \mathbf{Z} \hat{\Omega}^{-1} \mathbf{Z} \overline{\mathbf{X}}^{-1}\right.$,

where $\theta$ is the vector of parameters of interest $(\alpha, \beta), \overline{\mathbf{y}}$ is the dependent variable stacked first in differences and then in levels, $\overline{\mathbf{X}}$ is the explanatory-variable matrix including the lagged dependent variable $\left(y_{t-1}, X\right)$ stacked first in differences and then in levels, $\mathbf{Z}$ is the matrix of instruments derived from the moment conditions, and $\hat{\Omega}$ is a consistent estimate of the variance-covariance matrix of the moment conditions. ${ }^{8}$

Consistency of the GMM estimator depends on the validity of the instruments. To address this issue, we consider a Sargan-type specification

7. Given that lagged levels are used as instruments in the differences specification, only the most recent difference is used as an instrument in the levels specification. Using other lagged differences would result in redundant moment conditions (see Arellano and Bover, 1995).

8. Arellano and Bond (1991) suggest the following two-step procedure to obtain consistent and efficient GMM estimates. First, assume that the residuals, $\mathrm{e}_{i t}$, are independent and homoskedastic both across countries and over time. This assumption corresponds to a specific weighting matrix that is used to produce first-step coefficient estimates. Second, construct a consistent estimate of the variance-covariance matrix of the moment conditions with the residuals obtained in the first step, and use this matrix to reestimate the parameters of interest (that is, second-step estimates). Asymptotically, the second-step estimates are superior to the first-step ones in so far as efficiency is concerned. 
test. This test of overidentifying restrictions examines the overall validity of the instruments by analyzing the sample analog of the moment conditions used in the estimation process.

\subsection{Basic Results}

Table 4 presents the basic estimation results. The Sargan test cannot reject the null hypothesis of correct specification of our model. The estimated coefficients on most explanatory variables have the expected sign and are statistically significant. First, economic growth is affected by economic characteristics of development. The growth rate thus rises with a lower initial level of output (relative convergence effect), better education and health of the population, and deeper financial markets. Although openness to international trade has a positive estimated coefficient, it is not statistically significant in the basic regression, although it becomes so in the expanded model. Second, economic growth is shaped by the country's type of government. Consequently, the growth rate rises with smaller government size and a lower black market premium (less relative price distortions). Third, current international conditions also determine economic growth, such that the growth rate is higher in countries that face positive terms-of-trade shocks. The negative and significant coefficient on the period dummy variable indicates that the period 1985-1998 was less propitious for growth throughout the world than the previous fifteen years.

Our regression model can be used to explain the changes over time in economic growth for any country in the sample. We cannot, however, explain the levels of growth, given that we do not estimate the unobserved country-specific effects (although we control for them). We are interested in assessing the extent to which our model can account for the different growth performance before and after 1985. We use the regression point estimates and the actual changes in the explanatory variables to construct the regression projections.

Our projection results for Chile and a few other Latin American countries are presented in table 5. The accuracy of the projection is not satisfactory in most cases. Only for Colombia and Mexico does the projected growth difference closely approximate its actual value. Brazil and Ecuador performed considerably below what the regression projected, while Argentina, Peru, and especially Chile performed beyond their projections.

The actual improvement in Chile's growth rate after 1985 relative to the previous fifteen years was 4.74 percentage points. Our 
Table 4. Determinants of Economic Growth, Basic Regression $^{\mathbf{a}}$

\begin{tabular}{lcc}
\hline Explanatory variable & Coefficient & Standard error \\
\hline Constant & 0.1405 & 0.1543 \\
Initial GDP per capita (in logs) & $-0.0206^{* *}$ & 0.0059 \\
Initial average years of schooling (in logs) & $0.0226^{* *}$ & 0.0068 \\
Life expectancy (in logs) & $0.0653^{*}$ & 0.0417 \\
Domestic credit to private sector (as ratio to GDP, in logs) & $0.0089^{*}$ & 0.0049 \\
Government consumption (as ratio to GDP, in logs) & $-0.0772^{*}$ & 0.4797 \\
Black market premium (in log of 1 + bmp) & $-0.0620^{* *}$ & 0.0274 \\
Openness (as ratio of exports plus imports to GDP, in logs) & 0.0033 & 0.0063 \\
Terms-of-trade shocks (log difference of the terms of trade) & $0.1912^{* *}$ & 1.7153 \\
Dummy 1986-98 versus 1970-85 & $-0.0127^{* *}$ & 0.0031 \\
Summary statistics & & \\
Sargan test ( $p$ value) & 0.152 & \\
No. countries & 46 & \\
No. observations & 138 & \\
\hline
\end{tabular}

* Significant at the 10 percent level.

** Significant at the 5 percent level.

a. The dependent variable is the growth rate of per capita GDP. The estimation technique is the GMM-IV system estimator described in Arellano and Bover (1995).

b. The null hypothesis is that the instruments are valid.

Table 5. Comparison of Actual and Projected Growth Changes for Selected Latin American Countries, Basic Regression 1986-1998 versus $1970-1985$

Percent

\begin{tabular}{lccc}
\hline Country & Actual & Projected & Residual $^{a}$ \\
\hline Argentina & 1.98 & -0.06 & 2.04 \\
Brazil & -2.87 & -0.85 & -2.02 \\
Chile & 4.74 & 2.08 & $2.67+$ \\
Colombia & -0.96 & -0.55 & -0.41 \\
Ecuador & -3.67 & 0.91 & $-4.58^{* *}$ \\
Mexico & -0.81 & -0.96 & 0.16 \\
Peru & 0.76 & -0.75 & 1.51 \\
\hline
\end{tabular}

** indicates that the residual is different from zero at the 5 percent significance level.

+ indicates that the residual is different from zero at the 12 percent significance level.

a. The standard deviation for the residuals is $1.6478 \%$ for the $1986-1998$ period. 


\section{Figure 8. Histogram of Residuals, Basic Regression}

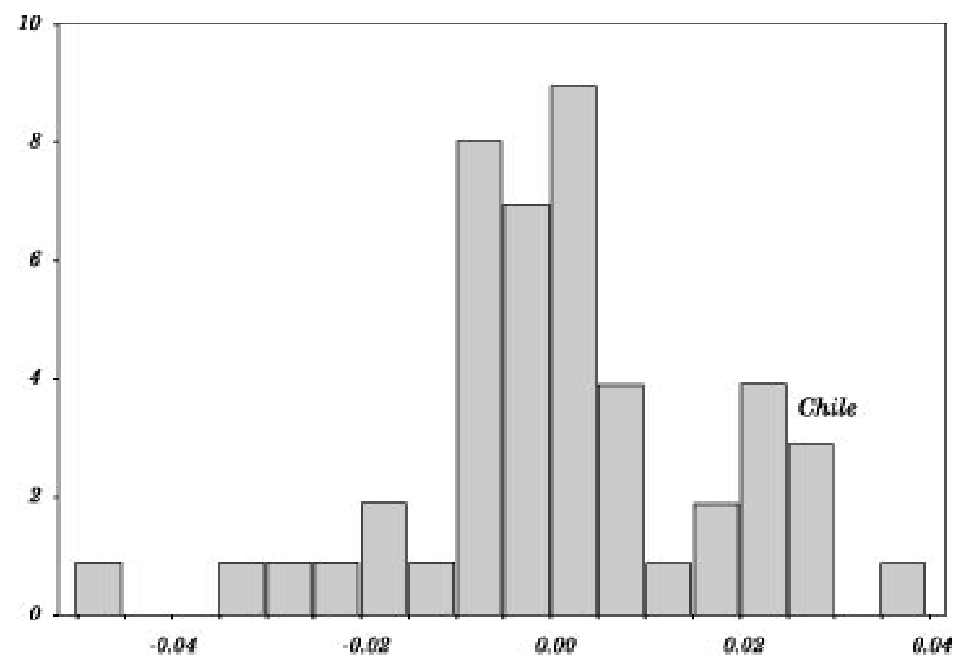

basic regression can account for only about 45 percent of the growth acceleration. The growth residual for Chile is 2.67 percentage points. This is one of the highest residuals of the sample, lying in the 12 percent upper tail of the distribution (see the histogram of residuals in figure 8.)

In the first column of table 6 , we assess the contribution of each explanatory variable to the projected difference in Chile's growth rate. (The second column presents the same exercise for the expanded regressions; the results are discussed below.) The variables that represent international conditions had contrasting effects that almost cancel each other: while positive terms-of-trade shocks contributed to more than a 1 percentage-point increase in Chile's growth rate after 1985, negative international growth conditions subtracted more than 1 percentage point over the same period. The combined effect of the human capital variables (education and life expectancy) was slightly over 1 percentage point. The increased depth of Chilean financial markets contributed about 0.75 percentage points to the growth acceleration, and a similar contribution resulted from the combined effect of the reduction in the government distortion variables (government consumption and black market premium). The conditional convergence effect actually played in favor of growth after 1985, given that the initial level of per capita income in this period was slightly lower than in the early 1970s. 
Table 6. Sources of Growth: Change in Contribution to per Capita Growth Rate, 1986-1998 versus 1971-1985

\section{Percent}

\begin{tabular}{lcc}
\hline Source of growth & Basic regression & Expanded regression \\
\hline Actual change in growth & 4.74 & 4.74 \\
Projected change in growth & 2.08 & 3.47 \\
Initial per capita income & 0.07 & 0.14 \\
Initial average years of schooling & 0.38 & 0.37 \\
Life expectancy & 0.63 & 1.08 \\
Domestic credit to private sector & 0.72 & 0.15 \\
Government consumption & 0.50 & 0.70 \\
Black market premium & 0.32 & 0.45 \\
Openness & 0.11 & 0.39 \\
Terms-of-trade shocks & 1.13 & 0.91 \\
Time dummies & -1.27 & -2.34 \\
Civil liberties & - & 0.70 \\
Main telephone lines & - & 0.53 \\
Policy complementarities & - & 1.26 \\
Residual & 2.67 & 1.27 \\
Residual for Chile, alternative regressions & Residual & Pvalue \\
Simple (table 4) & 2.67 & 0.120 \\
Civil liberties (table 7, col. 1) & 2.34 & 0.354 \\
Main telephone lines (table 7, col. 2) & 2.43 & 0.263 \\
Policy complementarities (table 7, col. 4) & 1.78 & 0.333 \\
All (table 7, col. 5) & 1.49 & 0.544 \\
\hline
\end{tabular}

\subsection{Expanded Regression Model}

Given that the basic model could not explain more than half of the growth improvement in Chile after 1985, we now expand the regression model, still following a cross-national approach. We consider three aspects of economic reform and development that have received considerable attention in the recent literature. The first area concerns the political system and governance. This large area comprises several aspects of the institutional quality of government, including respect for civil and political rights, bureaucratic efficiency, absence of corruption, enforcement of contractual agreements, and prevalence of law and order. After the seminal work by Mauro (1995) and Knack and Keefer (1995), the political system and governance have received increasing attention as a key determinant of economic growth; see, for instance, 
Barro (1996), Kaufmann, Kraay, and Zoido-Lobatón (1999b), and the survey in Przeworski and Limongi (1993). The recent empirical growth literature uses various subjective indices to measure different aspects of the political system and governance and compare them across countries and over time. In general, these indices are highly mutually correlated, which suggests that the underlying processes they measure are very interdependent. We use the popular Gastil's civil liberties index from Freedom House as representative of all measures of political system and governance. In robustness exercises, we also consider the indices produced by Business Environmental Risk Intelligence (BERI) and by Political Risk Services in their publication, International Country Risk Guide (ICRG). The correlation coefficients between Gastil's index and the BERI and ICRG indices are 0.69 and 0.78, respectively, and the correlation between any of the three variables and their first principal component is at least 0.90 .

The second area involves the availability of public services and infrastructure. The importance of productive public services in generating long-run growth has been highlighted in the theoretical work of Barro (1990) and Barro and Sala-i-Martin (1992), among others. Such studies use a variety of strategies to model the role of public services. Some treat government services as classic public goods, while others consider that they may be subject to congestion. In some models, public services and infrastructure enter directly as inputs of the production function, while in others they serve to improve total factor productivity, and in still others public services affect the expected rate of return on investment by protecting property rights. In any case, their theoretical importance has been well established. Empirical studies confirm this conclusion. The work by Loayza (1996) and Calderón, Easterly, and Servén (2001) provides evidence on the positive role of public services and infrastructure in promoting economic growth.

There are a few alternative measures of public services and infrastructure. Among them, the variables with the largest cross-country and time-series coverage focus on the provision of infrastructure. We choose to work with telecommunications capacity, measured by the number of main telephone lines per capita. In robustness exercises, we consider alternative aspects of public infrastructure, namely, energy generation capacity (as megawatts of electricity produced per capita) and transport facilities (as kilometers of paved roads per capita). The correlation coefficient between telephone lines and electricity generated and paved roads are 0.80 and 0.72 , respectively. The correlation between any of the three variables and their first principal component is at least 0.90 . 
The third area deals with the comprehensiveness and complementarity of policy reforms. The main idea is that joint progress in the determinants of growth carries a premium over and above the sum of their independent effects on growth. This premium is derived from the positive interactions and synergies that occur among the factors that promote economic growth. The early theoretical work by Hirschman (1958) shows how stronger linkages among various productive sectors can lead to higher economic growth. Levine and Renelt (1992) emphasize the growth impact of groups of policies working jointly. More recently, Ortiz (2001) and Acemoglu and Zilibotti (2001) underscore the interaction between human capital and technological adoption in producing productivity improvements. Dollar and Burnside (2000) stress the connection between institutional development and external aid in the growth process of poor economies, while Aziz and Wescott (1997) empirically measure the premium derived from joint progress in several areas and its importance in explaining growth differences across countries. These are only a few examples of a rich literature that stresses the interactions among various factors such as foreign direct investment, education, institutional development, and financial depth in generating a growth premium.

As a proxy for the joint progress in policy-related growth determinants (that is, policy complementarities), we use a dummy variable that takes the value of 1 in countries where all measures of a set of policy indicators have values better than the corresponding world median, and 0 otherwise. These indicators are taken from the basic model's explanatory variables, and they are related to openness, the black market premium, government consumption, financial development, life expectancy, and education. In the last period (1986-1998), the countries with a value of 1 in the policy complementarities dummy variable are Belgium, Chile, Ireland, Korea, the Netherlands, the Philippines, and Thailand. ${ }^{9}$

As shown in Figure 7, Chile's improvement in civil liberties, the number of telephone lines per capita, and the policy complementarities binary indicator in the periods 1970-85 and 1986-1998 is nothing short of remarkable.

Table 7 presents the results of the expanded regressions. In the first three columns, each of the additional explanatory variables is included in turn. The fourth column includes all of them jointly. Civil liberties, telephone lines per capita, and the dummy variable for policy

9. In 1960-1970, they are Belgium, Japan, and Norway; in 1971-1985, they are Greece, Ireland, Israel, Japan, the Netherlands, and Spain. 
Table 7. Determinants of Economic Growth, Expanded Regression $^{\text {a }}$

\begin{tabular}{|c|c|c|c|c|}
\hline Explanatory variable & (1) & (2) & (3) & (4) \\
\hline Constant & $\begin{array}{c}0.1465 \\
(0.1385)\end{array}$ & $\begin{array}{l}-0.0438 \\
(0.1397)\end{array}$ & $\begin{array}{c}0.1942 \\
(0.1553)\end{array}$ & $\begin{array}{c}0.2284 \\
(0.1589)\end{array}$ \\
\hline $\begin{array}{l}\text { Initial per capita GDP } \\
\text { (in logs) }\end{array}$ & $\begin{array}{c}-0.0182^{* *} \\
(0.0065)\end{array}$ & $\begin{array}{c}-0.0534^{* *} \\
(0.0079)\end{array}$ & $\begin{array}{c}-0.0191^{* *} \\
(0.0039)\end{array}$ & $\begin{array}{c}-0.0427^{* *} \\
(0.0064)\end{array}$ \\
\hline $\begin{array}{l}\text { Initial average years of schooling } \\
\text { (in logs) }\end{array}$ & $\begin{array}{l}0.0181^{* *} \\
(0.0088)\end{array}$ & $\begin{array}{c}0.021248^{* *} \\
-0.00657\end{array}$ & $\begin{array}{l}0.0222^{* *} \\
(0.0069)\end{array}$ & $\begin{array}{c}0.0219^{* *} \\
(0.0058)\end{array}$ \\
\hline $\begin{array}{l}\text { Life expectancy } \\
\text { (in logs) }\end{array}$ & $\begin{array}{c}0.0418 \\
(0.0453)\end{array}$ & $\begin{array}{l}0.1890 * * \\
(0.0305)\end{array}$ & $\begin{array}{l}0.1961^{* *} \\
(0.0576)\end{array}$ & $\begin{array}{l}0.1126^{* *} \\
(0.0293)\end{array}$ \\
\hline $\begin{array}{l}\text { Domestic credit to private sector } \\
\text { (as ratio to GDP, in logs) }\end{array}$ & $\begin{array}{c}0.0086^{*} \\
(0.0048)\end{array}$ & $\begin{array}{c}0.0080^{*} \\
(0.0050)\end{array}$ & $\begin{array}{c}0.0037 \\
(0.0035)\end{array}$ & $\begin{array}{c}0.0019 \\
(0.0051)\end{array}$ \\
\hline $\begin{array}{l}\text { Government consumption } \\
\text { (as ratio to GDP, in logs) }\end{array}$ & $\begin{array}{l}-0.0682 \\
(0.0463)\end{array}$ & $\begin{array}{c}-0.1136^{* *} \\
(0.0488)\end{array}$ & $\begin{array}{r}-0.0531^{*} \\
(0.0332)\end{array}$ & $\begin{array}{c}-0.1072^{* *} \\
(0.0342)\end{array}$ \\
\hline $\begin{array}{l}\text { Black market premium } \\
\text { (in log of } 1+\text { bmp) }\end{array}$ & $\begin{array}{r}-0.0443^{*} \\
(0.0232)\end{array}$ & $\begin{array}{c}-0.0841^{* *} \\
(0.0225)\end{array}$ & $\begin{array}{c}-0.0696^{* *} \\
(0.0267)\end{array}$ & $\begin{array}{c}-0.0857^{* *} \\
(0.0177)\end{array}$ \\
\hline $\begin{array}{l}\text { Openness (as ratio of exports } \\
\text { plus imports to GDP, in logs) }\end{array}$ & $\begin{array}{l}-0.0015 \\
(0.0056)\end{array}$ & $\begin{array}{l}0.0150^{* *} \\
(0.0046)\end{array}$ & $\begin{array}{l}-0.0031 \\
(0.0050)\end{array}$ & $\begin{array}{l}0.0120^{* *} \\
(0.0029)\end{array}$ \\
\hline $\begin{array}{l}\text { Terms-of-trade shocks } \\
\text { (log difference of the terms of trade) }\end{array}$ & $\begin{array}{l}0.1613^{* *} \\
(0.0497)\end{array}$ & $\begin{array}{l}0.1799 * * \\
(0.0365)\end{array}$ & $\begin{array}{l}0.1961^{* *} \\
(0.0576)\end{array}$ & $\begin{array}{l}0.1540^{* *} \\
(0.0300)\end{array}$ \\
\hline Dummy 1986-1998vs. $1970-1985$ & $\begin{array}{c}-0.0098^{* *} \\
(0.0032)\end{array}$ & $\begin{array}{c}-0.0272^{* *} \\
(0.0034)\end{array}$ & $\begin{array}{c}-0.0122^{* *} \\
(0.0023)\end{array}$ & $\begin{array}{c}-0.0216^{* *} \\
(0.0025)\end{array}$ \\
\hline Civil liberties (Gastil) & $\begin{array}{l}0.0182^{* *} \\
(0.0084)\end{array}$ & - & - & $\begin{array}{l}0.0161^{* *} \\
(0.0080)\end{array}$ \\
\hline $\begin{array}{l}\text { Main telephone lines } \\
\text { (as lines per } 1000 \text { workers) }\end{array}$ & - & $\begin{array}{l}0.0820^{* *} \\
(0.0150)\end{array}$ & - & $\begin{array}{l}0.0690^{* *} \\
(0.0130)\end{array}$ \\
\hline Policy complementarities & - & - & $\begin{array}{l}0.0147^{*} \\
(0.0084)\end{array}$ & $\begin{array}{l}0.0126^{* *} \\
(0.0052)\end{array}$ \\
\hline $\begin{array}{l}\text { Summary statistics } \\
\text { Sargan test }(p \text { value })^{b} \\
\text { No. countries } \\
\text { No. observations }\end{array}$ & $\begin{array}{c}0.126 \\
46 \\
138\end{array}$ & $\begin{array}{c}0.668 \\
46 \\
138\end{array}$ & $\begin{array}{c}0.248 \\
46 \\
138\end{array}$ & $\begin{array}{c}0.858 \\
46 \\
138\end{array}$ \\
\hline
\end{tabular}

* Significant at the 10 percent level.

** Significant at the 5 percent level.

a. The dependent variable is the growth rate of per capita GDP. The estimation technique is the GMM-IV system

estimator described in Arellano and Bover (1995). Standard errors are in parentheses.

b. The null hypothesis is that the instruments are valid. 
complementarities enter significantly in their respective regressions and with a positive sign that denotes a growth-improving effect. The sign and significance of their growth effects are maintained when the three variables are jointly included in the regression, although the point estimates are somewhat reduced. The estimated coefficients on the other variables have the same sign as in the basic model, but their size and significance changes in a couple of cases. The coefficient on openness increases in size and becomes statistically significant, while the opposite occurs with the ratio of private domestic credit to GDP.

We also conduct robustness exercises on the additional variables of the expanded model. ${ }^{10}$ For the political system and governance, we replace the civil liberties index with, in turn, the ICRG index, the BERI index, and the first principal component of the three indices. In each case, the estimated coefficient is positive and statistically significant. For public services and infrastructure, we replace the number of telephones per capita with, in turn, the measures of paved roads and electricity generation, as well as the first principal component of the three infrastructure indicators. The corresponding estimated coefficient is positive in all cases, but it is statistically significant only when the number of telephone lines and the first principal component are used. Finally, for the policy complementarities indicator, we run the regression excluding Chile from the sample to dispel fears that it may be simply representing a Chile-specific dummy variable. The results are basically unchanged, and the estimated coefficient on policy complementarities remains significantly positive and even increases in absolute value.

With the additional explanatory variables, we reassess the regression's ability to account for Chile's growth improvement after 1985 relative to the previous fifteen years. The corresponding results are presented in the second column of table 6 . By including the variables on the political system and governance, public services and infrastructure, and policy complementarities, we can account for 73 percent of the growth improvement. The contribution of public infrastructure to the growth acceleration in Chile is similar to the contribution of the increase in openness, the expansion of education, or the diminution of the black market premium. The contribution of civil liberties is even higher, on the level of the reduction in government consumption. The most remarkable result in the expanded regression is the large contribution of policy complementarities, which at 1.26 percentage points surpasses that of larger positive terms-of-trade shocks and enhanced

10. The results of these exercises are available on request. 
life expectancy. This indicates that a comprehensive reform strategy that targets all policy fronts carries an important premium over the positive, independent effect of isolated policy improvements. It appears to be an important growth determinant in other high-performing countries, such as Ireland, Korea, the Netherlands, and Thailand.

Although the additional variables have improved the regression's explanatory power, we still fail to account for about 27 percent of the actual increase in the Chilean growth rate after 1985. A cross-country approach is unlikely to advance any further in this regard. We have already included the most relevant variables for this type of econometric exercise, and other variables are likely to be highly correlated with those already present in the model. Still, one possibility is that we have left out some important variables that are difficult to measure and that relate specifically to Chilean economic development. A more likely explanation, however, is that some of the growth gains after 1985 do not reflect long-run developments, but rather represent a cyclical recovery from the recessionary periods of the early 1970s and early 1980s. ${ }^{11}$

\section{Growth in the Future}

What can Chile expect in the way of economic growth in the future? Put differently, what is Chile's growth potential? A proper answer to these questions calls for a comprehensive, multifaceted approach. Here, we address the issue of Chile's future growth from the perspective of cross-national empirical results. We use the estimates obtained in our cross-country, panel regressions to forecast economic growth in Chile in the next ten years, working under alternative assumptions for the behavior of the variables that drive growth.

We begin by projecting growth under the assumption that the explanatory variables continue their past trends into the next decade. First, we estimate a linear, logarithmic, or quadratic trend-whichever provides the best fit- to each explanatory variable. The exceptions are initial per capita income and average years of educational attainment, for which we simply take a value at the start of the forecasting period (specifically, an average of the years surrounding 2000). A third exception concerns the black market premium on foreign exchange; in this case we assume that the current exchange rate policies (free-floating system

11. Another potential explanation has to do with error of measurement in GDP. Preliminary estimates show that in 1997-1998, the old National Accounts overestimated GDP growth by roughly 0.75 percent per year. 
with a liberal capital account) remain unchanged into the next decade. Second, we use the estimated regression coefficients to project the contribution of each variable to growth in the next decade. The results are presented in the first panel of table 8. The first column shows the values of the explanatory variables corresponding to the period 1986-1998, and the second column shows their respective values used in the growth projection for the next decade. The last two columns present the growth forecast under the simple and expanded models, respectively. The main conclusion from this exercise is that if the evolution of growth determinants follows the same trends as in the past, the per capita GDP growth rate in the next decade will be between one-half and three-quarters of a percentage point less than it was during 1986-1998.

Under this "continuing trend" assumption, therefore, we project a slight decrease in Chile's growth rate. The fall in the growth rate occurs despite an improvement in most explanatory variables. The only variable that is projected to reduce growth is the terms of trade, which are expected to present less favorable shocks in the future. Improvements in human capital, government efficiency, the financial market, and particularly public infrastructure are projected to have a beneficial impact on economic growth. However, this combined positive effect is not large enough to overcome the forces of conditional convergence stemming from decreasing marginal returns. The fact that the initial income in 2001 is more than twice as large as the initial income in 1986 weighs heavily against growth in the next decade.

Our second projection for Chilean growth in the next decade is based on the assumption that Chile is able to jump to at least the ninetieth percentile of the world distribution for each variable that drives growth in our model. This sharp progress is admittedly unrealistic because improvements in human capital, government efficiency, infrastructure, financial depth, and governance take a long time to materialize and are usually accompanied by increases in income, which in turn lead to lower growth. The exercise may be valuable, however, because it helps establish some upper bounds for what can be expected for growth in Chile under a strong process of development and economic reforms.

The second panel of table 8 presents the results of the second projection. According to the basic model, by accessing the top 10 percent in growth determinants, Chile would obtain 0.24 percentage points higher growth than in the past fifteen years. This growth acceleration would mainly be due to improvements in schooling, financial intermediation, and reductions in price distortions (represented by the black market premium). The expanded model is even more optimistic, as it predicts 
Table 8. Growth Forecasts under Different Scenarios ${ }^{\text {a }}$ Change in per capita growth rate

\begin{tabular}{|c|c|c|c|c|}
\hline \multirow{2}{*}{$\begin{array}{l}\text { Assumption and source } \\
\text { of growth } \\
\text { A. Continuing trend }\end{array}$} & \multicolumn{2}{|c|}{$\begin{array}{l}\text { Actual and } \\
\text { projected values }\end{array}$} & \multicolumn{2}{|c|}{$\begin{array}{l}\text { Projected change in growth } \\
\text { (percentage points) }\end{array}$} \\
\hline & $\begin{array}{c}\text { Actual } \\
1986-1998\end{array}$ & $\begin{array}{l}\text { Projected } \\
2001-2010\end{array}$ & $\begin{array}{l}\text { Basic } \\
\text { regression }\end{array}$ & $\begin{array}{l}\text { Expanded } \\
\text { regression }\end{array}$ \\
\hline Growth rate of GDP per capita (percent) & 4.52 & & -0.45 & -0.70 \\
\hline Initial per capita income $\mathrm{e}^{\mathrm{b}}$ & 4,236 & 9,702 & -1.71 & -3.54 \\
\hline Initial average years of schooling ${ }^{b}$ & 6.87 & 7.55 & 0.21 & 0.21 \\
\hline Life expectancy & 74.29 & 77.15 & 0.25 & 0.43 \\
\hline Domestic credit to private sector (percent) & t) 56.5 & 87.70 & 0.39 & 0.08 \\
\hline Government consumption (percent) & 9.20 & 7.30 & 0.18 & 0.21 \\
\hline Black market premium (percent) & 11.10 & 0.00 & 0.65 & 0.90 \\
\hline Openness (percent) & 75.50 & 93.90 & 0.07 & 0.22 \\
\hline Terms-of-trade shocks (percent) & 0.89 & -1.72 & -0.50 & -0.40 \\
\hline Civil liberties & 0.71 & 0.83 & - & 0.20 \\
\hline Main telephone lines & 109.09 & 253.07 & - & 0.99 \\
\hline Policy complementarities & 1.00 & 1.00 & - & 0.00 \\
\hline B. Sharp progress & $\begin{array}{c}\text { Actual } \\
1986-1998\end{array}$ & $\begin{array}{l}\text { Projected } \\
2001-2010\end{array}$ & $\begin{array}{l}\text { Basic } \\
\text { regression }\end{array}$ & $\begin{array}{l}\text { Expanded } \\
\text { regression }\end{array}$ \\
\hline Growth rate of GDP per capita (percent) & 4.52 & & 0.24 & 2.04 \\
\hline Initial per capita income $\mathrm{b}^{\mathrm{b}}$ & 4,236 & 9,702 & -1.71 & -3.54 \\
\hline Initial average years of schooling ${ }^{b}$ & 6.87 & 9.27 & 0.68 & 0.66 \\
\hline Life expectancy & 74.29 & 77.15 & 0.25 & 0.43 \\
\hline Domestic credit to private sector (percent) & t) 56.50 & 103.40 & 0.54 & 0.11 \\
\hline Government consumption (percent) & 9.20 & 7.30 & 0.18 & 0.21 \\
\hline Black market premium (percent) & 11.10 & 0.00 & 0.65 & 0.90 \\
\hline Openness (percent) & 75.50 & 119.7 & 0.15 & 0.55 \\
\hline Terms-of-trade shocks (percent) & 0.89 & -1.72 & -0.50 & -0.40 \\
\hline Civil liberties & 0.71 & 1.00 & - & 0.46 \\
\hline Main telephone lines & 109.09 & 494.79 & - & 2.66 \\
\hline Policy complementarities & 1.00 & 1.00 & - & 0.00 \\
\hline C. Sharp progress in three new areas & $\begin{array}{c}\text { Actual } \\
1986-1998\end{array}$ & $\begin{array}{l}\text { Projected } \\
2001-2010\end{array}$ & $\begin{array}{l}\text { Addi } \\
\text { regr }\end{array}$ & $\begin{array}{l}\text { ional } \\
\text { sion }\end{array}$ \\
\hline Quality of education & -0.96 & 0.60 & & \\
\hline Microeconomic restrictions & 12.00 & 5.00 & & \\
\hline Technology adoption & 15.37 & 191.15 & & \\
\hline
\end{tabular}

a. The variables are defined as in the cross-country regressions. Panel A (continuous trend) projects growth under the assumption that the explanatory variables continue their past trends into the next decade. Panels B and $\mathrm{C}$ (sharp progress) are based on the assumption that Chile is able to jump to at least the ninetieth percentile of the world distribution for each variable that drives growth in the model.

b. Values for these variables correspond to the start of the relevant period.

c. Additional regressions (see table 9). 
an increase in the growth rate of 2.04 percentage points. In this case, the main contributors are improvements in schooling, openness, price distortions, and, most importantly, public infrastructure.

Our search for factors that explain the remarkable growth acceleration in Chile after 1985 concentrated on those variables for which we have data for the various periods under consideration. This may have excluded some relevant variables for which only cross-country data are available. Given that our focus in this section is on the prospects for growth in Chile, we can go back to the question of what drives growth and consider variables for which we only have cross-sectional information. We thus consider three new areas. The first is the quality of education. As Barro (2001) and Hanushek and Kimko (2000) point out, the average number of years of schooling is only a rough proxy for human capital in the educational dimension. It needs to be complemented by measures of educational quality, such as those derived from standardized test scores. We use the series in Barro and Lee (2000) and Hanushek and Kimko (2000), complemented by the TIMSS international test scores, to construct an index of the quality of education for a sample of forty-two countries (see appendix B for details).

The second new area concerns microeconomic restrictions-or more precisely, the regulatory obstacles to the establishment of new enterprises. As de Soto, Ghersi, and Ghibellini (1986) vividly illustrate in their study on red tape in Peru, entry restrictions for new enterprises can be a serious obstacle to economic development. Following de Soto's ideas, Djankov and others (2000) recently constructed a measure of entry restrictions for a large sample of countries. We include this measure in our growth regressions.

Finally, the third area is related to technological adoption. Whether a country develops or copies new technologies, its capacity and willingness to assimilate new methods of production are bound to affect its growth potential (see, for instance, Young, 1989, chap. 6; Romer, 1992; Beaudry and Green, 2001; Keller, 2001). In a recent paper, Caselli and Coleman (2001) use the number of imported computers as a proxy for technological adoption in a sample of countries. We follow their example in using this measure in our growth regressions.

Our purpose here is to obtain an estimate of the beneficial growth impact of Chile's advancing in the areas of educational quality, microeconomic restrictions, and technological adoption. We first need an estimate of the effect of each of these variables on growth, which we obtain by adding each variable to our basic model, one by one. The results are presented in table 9 . The estimated coefficients are significant, 
Table 9. Determinants of Economic Growth, Additional Factors $^{\text {a }}$

\begin{tabular}{|c|c|c|c|}
\hline Explanatory variable & (1) & (2) & (3) \\
\hline Constant & $\begin{array}{c}0.3889 \\
(0.1883)\end{array}$ & $\begin{array}{l}-0.1845 \\
(0.1419)\end{array}$ & $\begin{array}{c}0.0903 \\
(0.1661)\end{array}$ \\
\hline $\begin{array}{l}\text { Initial per capita GDP } \\
\text { (in logs) }\end{array}$ & $\begin{array}{c}-0.0091 \\
(0.0057)\end{array}$ & $\begin{array}{c}-0.0126^{* *} \\
(0.0054)\end{array}$ & $\begin{array}{r}-0.0280^{* *} \\
(0.0062)\end{array}$ \\
\hline $\begin{array}{l}\text { Initial average years of schooling } \\
\text { (in logs) }\end{array}$ & $\begin{array}{r}-0.0148^{*} \\
(0.0080)\end{array}$ & $\begin{array}{l}-0.0115 \\
(0.0090)\end{array}$ & $\begin{array}{l}0.0187 * * \\
(0.0074)\end{array}$ \\
\hline $\begin{array}{l}\text { Life expectancy } \\
\text { (in logs) }\end{array}$ & $\begin{array}{c}0.0375 \\
(0.0394)\end{array}$ & $\begin{array}{l}0.1598 * * \\
(0.0246)\end{array}$ & $\begin{array}{l}0.1108^{* *} \\
(0.0393)\end{array}$ \\
\hline $\begin{array}{l}\text { Domestic credit to private sector } \\
\text { (as ratio to GDP, in logs) }\end{array}$ & $\begin{array}{c}0.0012 \\
(0.0025)\end{array}$ & $\begin{array}{c}-0.0059 \\
(0.0041)\end{array}$ & $\begin{array}{c}0.0048 \\
(0.0036)\end{array}$ \\
\hline $\begin{array}{l}\text { Government consumption } \\
\text { (as ratio to GDP, in logs) }\end{array}$ & $\begin{array}{l}0.0614^{* *} \\
(0.0216)\end{array}$ & $\begin{array}{c}-0.0799 * * \\
(0.0287)\end{array}$ & $\begin{array}{l}-0.0408 \\
(0.0312)\end{array}$ \\
\hline $\begin{array}{l}\text { Black market premium } \\
\text { (in log of } 1+\mathrm{bmp} \text { ) }\end{array}$ & $\begin{array}{c}-0.0933^{* *} \\
(0.0123)\end{array}$ & $\begin{array}{c}-0.0752^{* *} \\
(0.0270)\end{array}$ & $\begin{array}{r}-0.0748^{* *} \\
(0.0229)\end{array}$ \\
\hline $\begin{array}{l}\text { Openness (as ratio of exports } \\
\text { plus imports to GDP, in logs) }\end{array}$ & $\begin{array}{l}-0.0007 \\
(0.0043)\end{array}$ & $\begin{array}{l}0.0145^{* *} \\
(0.0044)\end{array}$ & $\begin{array}{c}0.0025 \\
(0.0048)\end{array}$ \\
\hline $\begin{array}{l}\text { Terms-of-trade shocks } \\
\text { (log difference of the terms of trade) }\end{array}$ & $\begin{array}{l}0.1156^{* *} \\
(0.0482)\end{array}$ & $\begin{array}{l}0.1813^{* *} \\
(0.0700)\end{array}$ & $\begin{array}{l}0.1708^{* *} \\
(0.0497)\end{array}$ \\
\hline Dummy 1986-1998vs. 1970-1985 & $\begin{array}{l}-0.0028 \\
(0.0028)\end{array}$ & $\begin{array}{c}-0.0137 * * \\
(0.0022)\end{array}$ & $\begin{array}{c}-0.0178^{* *} \\
(0.0027)\end{array}$ \\
\hline $\begin{array}{l}\text { Quality of education } \\
\text { (as a normalized index) }\end{array}$ & $\begin{array}{l}0.0095^{* *} \\
(0.0049)\end{array}$ & - & - \\
\hline $\begin{array}{l}\text { Microeconomic restrictions } \\
\text { (no. procedures to open a firm) }\end{array}$ & - & $\begin{array}{c}-0.0011^{* *} \\
(0.0005)\end{array}$ & - \\
\hline $\begin{array}{l}\text { Technology adoption } \\
\text { (imported computers per worker) }\end{array}$ & - & - & $\begin{array}{l}0.0001^{* *} \\
(0.0000)\end{array}$ \\
\hline $\begin{array}{l}\text { Summary statistics } \\
\text { Sargan test }(p \text { value })^{b} \\
\text { No. countries } \\
\text { No. observations }\end{array}$ & $\begin{array}{c}0.146 \\
42 \\
126\end{array}$ & $\begin{array}{c}0.261 \\
37 \\
111\end{array}$ & $\begin{array}{c}0.236 \\
44 \\
132\end{array}$ \\
\hline
\end{tabular}

* Significant at the 10 percent level.

** Significant at the 5 percent level.

a. The dependent variable is the growth rate of per capita GDP. The estimation technique is the GMM-IV system

estimator described in Arellano and Bover (1995). Standard errors are in parentheses.

b. The null hypothesis is that the instruments are valid. 
carry the expected sign, and appear to be economically important, as discussed below. ${ }^{12}$ We should note, however, that since these coefficients are estimated considering only the basic model, part of their effect might be captured by the variables of the expanded model or the variables representing the other new areas.

Following our "sharp progress" assumptions, we measure the growth impact that the economy would experience if Chile were to jump to the top 10 percent of the world in the three new areas over the next decade. The results are presented in the third panel of table 8. A comparison of the second and first columns shows that Chile is still far behind the best countries in all three areas, particularly technological adoption. This large gap, coupled with the size of the regression coefficients, implies that Chile can make potentially large gains from advancing in the three areas, especially the quality of education. Improvements in microeconomic restrictions would increase growth by three-quarters of a percentage point; in technological adoption, by a little over one percent; and in educational quality, by close to one and a half percentage point (see column 3).

\section{Conclusions}

Economic growth in Chile since the mid-1980s has been remarkable for its high level and persistence. The country, however, has not been immune to the wave of international crises in the late 1990s, and many people now wonder whether the golden period of growth in Chile is a thing of the past. This paper examines the factors behind the high growth rates of the last fifteen years and analyzes the extent to which they can be sustained in the future.

To this end, we present a set of stylized facts on economic growth in Chile, which allows us to identify the issues that deserve further investigation. First, Chile's growth performance in the last fifteen years has been substantially higher and less volatile than in the typical country in Latin America and the world. For Chile, the 1980s did not represent a lost decade, as it did in most of Latin America. Second, an analysis of sectoral value added shows that high growth in Chile was balanced across sectors, which suggests that growth was prompted by suitable

12. It is interesting to note that when the quality-of-education variable is added to the basic regression, the coefficient on average years of schooling becomes negative. This could support the view that the quality of education is more important for economic growth than the quantity. 
general macroeconomic conditions. Third, growth accounting exercises indicate that the expansion of growth in the latter period is driven by a combination of capital accumulation, labor expansion, and, particularly, a significant increase in TFP. Finally, dynamic analysis suggests that Chile's high growth followed - rather than preceded-domestic investment and external financing. Taken together, these stylized facts suggest that the jump in growth was driven by policies and macroeconomic conditions that affected the economy's overall productivity.

Given these stylized facts, our first analytic objective is to explain the sharp change in the growth rate in Chile after 1985. There are several potential ways to address this issue; given our comparative advantage, we chose an international perspective. On considering the large body of recent empirical growth literature, we examine the extent to which a cross-country approach can explain Chile's growth performance. We formulate a basic regression model that contains the most popular variables in the growth literature and estimate it using techniques suited for dynamic models of panel data. Our basic model allows us to explain about 45 percent of the change in the growth rate between 1970-1985 and 1986-1998, which was 4.74 percentage points. We find that the variables that represent international conditions had contrasting effects that nearly cancel each other out. The combined effect of human capital variables was slightly over 1 percentage point. The increased depth of Chilean financial markets contributed about 0.75 percentage points to the growth acceleration, and a similar contribution resulted from the combined effect of the reduction in the variables that accounted for government-induced distortions.

We then extend the basic model in a quest to explain a higher fraction of the growth acceleration. We include variables that have recently received attention in the growth literature. The expanded model explains about 73 percent of the increase in the growth rate after 1985 . Improvements in the political system and public infrastructure contribute a little more than one-half of a percentage point each, while a binary indicator that served as a proxy for the comprehensiveness of policy reforms accounts for more than one percentage point of the increase in the growth rate. The last result is particularly interesting as it signals the existence of a growth premium for advancing the policy reform agenda on several fronts at the same time.

The last section of the paper assesses what can be expected with regard to growth in Chile over the next decade. Continuing with the cross-country empirical approach, we estimate that if the variables that drive growth continue their past trends into the future, the growth 
rate of per capita GDP in the next decade will decrease by one-half to three-quarters of a percentage point relative to the rate in 1986-1998. The growth rate would fall despite projected improvements in human capital, government efficiency, financial market, and public infrastructure because their combined positive effect is not large enough to offset the forces of conditional convergence. This fall in the growth rate could be prevented if the country follows an admittedly difficult path of sharp progress in economic reform.

Finally, we search for new sources of economic growth for a country, like Chile, that has already advanced in the basic determinants of growth. After combining the results from these rather tentative exercises with those from our basic and expanded models, we conclude that Chile can increase its future growth by focusing on the provision of public infrastructure and the enhancement of the quantity and quality of education. Improving governance, eliminating excessive regulatory restrictions, and encouraging technology adoption also appear to be promising avenues for increasing economic growth. 


\section{APPENDIX A}

\section{Sample of Countries by Region}

Our sample consists of a balanced panel of forty-six countries, which we selected based on the availability of data on relevant variables and not by arbitrary selection. It includes twenty-two developed and twentyfour developing countries, with fifteen from Latin America and the Caribbean. The complete list is as follows:

- East Asia and the Pacific (four countries): Indonesia, Korea, the Philippines, and Thailand.

- High-income economies (twenty-two countries): Australia, Austria, Belgium, Canada, Denmark, Finland, France, Germany, Greece, Ireland, Israel, Italy, Jamaica, Japan, the Netherlands, New Zealand, Norway, Portugal, Spain, Sweden, the United Kingdom, and the United States.

- Latin America and the Caribbean (fifteen countries): Argentina, Brazil, Chile, Colombia, Costa Rica, the Dominican Republic, Ecuador, El Salvador, Guatemala, Honduras, Mexico, Paraguay, Peru, Trinidad and Tobago, and Uruguay.

- South Asia (one country): Pakistan.

- Sub-Saharan Africa (four countries): Ghana, Niger, Senegal, and South Africa. 


\section{ApPendix B}

\section{Variables and Sources}

\begin{tabular}{|c|c|c|}
\hline Variable & Definition and construction & Source \\
\hline \multicolumn{3}{|l|}{ Output } \\
\hline $\begin{array}{l}\text { Real per capita GDP (in } \\
1990 \text { PPP US\$) }\end{array}$ & $\begin{array}{l}\text { Ratio of total GDP to total population. } \\
\text { GDP is in } 1990 \text { US } \$ \text { and is corrected to } \\
\text { make it internationally comparable } \\
\text { using PPP. }\end{array}$ & $\begin{array}{l}\text { Summers and Heston } \\
\text { (1991); World Bank (2000) }\end{array}$ \\
\hline $\begin{array}{l}\text { Real GDP (in } 1986 \\
\text { Chilean pesos) }\end{array}$ & $\begin{array}{l}\text { Constructed by splicing GDP in } 1977 \\
\text { pesos (from National Accounts, } \\
\text { 1960-1985) and GDP in } 1986 \text { pesos } \\
\text { (from National Accounts, 1985-2000). }\end{array}$ & $\begin{array}{l}\text { Central Bank of Chile } \\
\text { (2001); authors' } \\
\text { elaboration }\end{array}$ \\
\hline $\begin{array}{l}\text { Sectoral shares in total } \\
\text { value added (percent of } \\
\text { total value added) }\end{array}$ & $\begin{array}{l}\text { Constructed as percentage of total } \\
\text { value added by splicing GDP by } \\
\text { economic sector in 1977 pesos (from } \\
\text { National Accounts, } 1960-1985 \text { ) and } \\
\text { GDP by economic sector in 1986 pesos } \\
\text { (from National Accounts. 1985-2000) }\end{array}$ & $\begin{array}{l}\text { Central Bank of Chile } \\
\text { (2001); authors' } \\
\text { construction }\end{array}$ \\
\hline \multicolumn{3}{|l|}{$\begin{array}{l}\text { Physical } \\
\text { and human capital }\end{array}$} \\
\hline $\begin{array}{l}\text { Domestic capital stock } \\
\text { (in } 1986 \text { Chilean pesos) }\end{array}$ & $\begin{array}{l}\text { Constructed using the perpetual } \\
\text { inventory method. Depreciation rate is } 4 \\
\text { percent a year. We assumed a ratio of } \\
\text { capital to GDP of } 2.5 \text { in } 1940 \text {. Series of } \\
\text { gross capital formation are taken from } \\
\text { Bennett, Schmidt-Hebbel, and Soto (2000). }\end{array}$ & $\begin{array}{l}\text { Authors' construction } \\
\text { using Chilean National } \\
\text { Accounts and Bennett, } \\
\text { Schmidt-Hebbel, } \\
\text { and Soto (2000) }\end{array}$ \\
\hline $\begin{array}{l}\text { Investment } \\
\text { (percent of GDP) }\end{array}$ & $\begin{array}{l}\text { Ratio of gross domestic investment (in } \\
1986 \text { pesos) to GDP (in } 1986 \text { pesos). }\end{array}$ & $\begin{array}{l}\text { Bennett, Schmidt-Hebbel, } \\
\text { and Soto (2000); Central } \\
\text { Bank of Chile (2001) }\end{array}$ \\
\hline $\begin{array}{l}\text { National and foreign } \\
\text { saving (percent of GDP) }\end{array}$ & $\begin{array}{l}\text { Ratio of gross national (foreign) saving } \\
\text { (in } 1986 \text { pesos) to GDP (in } 1986 \text { pesos). }\end{array}$ & $\begin{array}{l}\text { Bennett, Schmidt-Hebbel, } \\
\text { and Soto (2000); Central } \\
\text { Bank of Chile (2001) }\end{array}$ \\
\hline Labor force, total & $\begin{array}{l}\text { Working-age population, taken from } \\
\text { several surveys. }\end{array}$ & $\begin{array}{l}\text { Central Bank of Chile } \\
\text { (2001); authors' } \\
\text { construction }\end{array}$ \\
\hline Employment, total & $\begin{array}{l}\text { Number of people actually working, } \\
\text { taken from several labor surveys. }\end{array}$ & $\begin{array}{l}\text { Central Bank of Chile } \\
\text { (2001); authors' } \\
\text { construction }\end{array}$ \\
\hline Average hours worked & $\begin{array}{l}\text { Average number of hours actually } \\
\text { worked, per worker. }\end{array}$ & $\begin{array}{l}\text { Occupation and } \\
\text { Employment Surveys of } \\
\text { University of Chile }\end{array}$ \\
\hline $\begin{array}{l}\text { Average years of } \\
\text { schooling }\end{array}$ & $\begin{array}{l}\text { Average number of years of schooling } \\
\text { in the population. }\end{array}$ & Barro and Lee (2000) \\
\hline
\end{tabular}




\section{APPENDIX B (continued)}

\begin{tabular}{|c|c|c|}
\hline Variable & Definition and construction & Source \\
\hline $\begin{array}{l}\text { Average years of } \\
\text { secondary schooling }\end{array}$ & $\begin{array}{l}\text { Average number of years of secondary } \\
\text { schooling in the population. }\end{array}$ & Barro and Lee (2000) \\
\hline $\begin{array}{l}\text { Life expectancy at birth } \\
\text { (years) }\end{array}$ & $\begin{array}{l}\text { Life expectancy at birth indicates the } \\
\text { number of years a newborn infant } \\
\text { would live if prevailing patterns of } \\
\text { mortality at the time of its birth were } \\
\text { to stay the same throughout its life. }\end{array}$ & World Bank (2000) \\
\hline $\begin{array}{l}\text { Labor force quality } \\
\text { (index) }\end{array}$ & $\begin{array}{l}\text { Normalized index constructed by } \\
\text { combining measures of standardized } \\
\text { test scores taken from several sources. } \\
\text { To make it comparable each observation } \\
\text { was normalized by subtracting each } \\
\text { test's average and dividing by each } \\
\text { test's standard deviation. Hence a value } \\
\text { of } n \text { means the observation is } n \\
\text { standard deviations distant from the } \\
\text { test average. }\end{array}$ & $\begin{array}{l}\text { Authors' construction, } \\
\text { based on Barro and Lee } \\
(2000) \text {, Hanushek and } \\
\text { Kimko (2000), and TIMSS } \\
(2000)\end{array}$ \\
\hline \multicolumn{3}{|l|}{ External sector } \\
\hline Terms-of-trade shocks & $\begin{array}{l}\text { Log difference of the terms of trade. } \\
\text { Terms of trade are defined as } \\
\text { customary. }\end{array}$ & World Bank (2000) \\
\hline $\begin{array}{l}\text { Openness } \\
\text { (percent of GDP) }\end{array}$ & $\begin{array}{l}\text { Ratio of the sum of real exports and } \\
\text { real imports to real GDP. }\end{array}$ & $\begin{array}{l}\text { Summers and Heston } \\
\text { (1991); World Bank (2000) }\end{array}$ \\
\hline \multicolumn{3}{|c|}{ Finance } \\
\hline $\begin{array}{l}\text { Domestic credit to the } \\
\text { private sector (percent of } \\
\text { GDP) }\end{array}$ & $\begin{array}{l}\text { Ratio of the stock of domestic credit to } \\
\text { the private sector to GDP. }\end{array}$ & $\begin{array}{l}\text { Beck, Demirgüç-Kunt, and } \\
\text { Levine (2000) }\end{array}$ \\
\hline \multicolumn{3}{|l|}{$\begin{array}{l}\text { Government-induced } \\
\text { distortions }\end{array}$} \\
\hline $\begin{array}{l}\text { Black market premium } \\
\text { (BMP) }\end{array}$ & $\begin{array}{l}\text { Calculated as (parallel exchange rate/ } \\
\text { official exchange rate) }-1 \text {. Values for } \\
\text { industrial countries are added as } 0 \text {. }\end{array}$ & $\begin{array}{l}\text { Wood (1988); International } \\
\text { Currency Analysis } \\
\text { (various issues) }\end{array}$ \\
\hline \multicolumn{3}{|c|}{ Democracy and governance } \\
\hline Civil liberties (index) & $\begin{array}{l}\text { Defined as rights to free expression, to } \\
\text { organize or demonstrate, and to a } \\
\text { degree of autonomy such as is provided } \\
\text { by freedom of religion, education, } \\
\text { travel, and other personal rights. } \\
\text { Countries are classified into seven } \\
\text { categories. The original ranking from } \\
\text { one to seven was converted here to a } \\
\text { scale of } 0 \text { to } 1 \text {, where } 0 \text { corresponds to } \\
\text { the fewest rights (rank seven) and } 1 \text { to } \\
\text { the most rights (rank one). }\end{array}$ & Freedom House \\
\hline
\end{tabular}




\section{APPENDIX B (continued)}

\begin{tabular}{|c|c|c|}
\hline Variable & Definition and construction & Source \\
\hline Law and order (index) & $\begin{array}{l}\text { A subjective index related to the } \\
\text { overall maintenance of the law and the } \\
\text { legal tradition of a country. The index } \\
\text { goes from } 0 \text { to } 6 \text {, where } 0 \text { indicates the } \\
\text { poorest maintenance of the rule of law } \\
\text { and } 6 \text { the best. }\end{array}$ & $\begin{array}{l}\text { International Country } \\
\text { Risk Guide (ICRG) }\end{array}$ \\
\hline Governance (index) & $\begin{array}{l}\text { The simple average of the following } \\
\text { subindexes: bureaucratic delay, contract } \\
\text { enforceability, nationalization risk, and } \\
\text { infrastructure quality. Each component } \\
\text { is measured on a scale of } 0 \text { to } 4 \text {. }\end{array}$ & $\begin{array}{l}\text { Business Environmental } \\
\text { Risk Intelligence }\end{array}$ \\
\hline $\begin{array}{l}\text { Microeconomic } \\
\text { distortions (number) }\end{array}$ & $\begin{array}{l}\text { Measure of the number of different } \\
\text { bureaucratic procedures necessary to } \\
\text { open a new business. It goes from } 2 \\
\text { (the lowest value, Canada) to } 20 \text { (the } \\
\text { highest value, Bolivia). }\end{array}$ & Djankov and others (2000) \\
\hline $\begin{array}{l}\text { Policy complementarities } \\
\text { (dummy variable) }\end{array}$ & $\begin{array}{l}\text { Dummy variable that takes the value of } \\
1 \text { if a country is above the world } \\
\text { median in secondary years of } \\
\text { schooling, life expectancy, domestic } \\
\text { credit to private sector, and openness; } \\
\text { and below the world median in } \\
\text { government consumption and black } \\
\text { market premium. Otherwise, the } \\
\text { variable equals } 0 \text {. }\end{array}$ & Authors' construction \\
\hline $\begin{array}{l}\text { Infrastructure } \\
\text { Main telephone lines per } \\
1000 \text { workers }\end{array}$ & $\begin{array}{l}\text { Telephone mainlines are telephone lines } \\
\text { connecting a customer's equipment to } \\
\text { the public switched telephone network. } \\
\text { Data are presented per } 1,000 \text { workers for } \\
\text { the entire country. }\end{array}$ & $\begin{array}{l}\text { Canning(1998), } \\
\text { International } \\
\text { Telecommunications Union }\end{array}$ \\
\hline $\begin{array}{l}\text { Energy generation } \\
\text { capacity }\end{array}$ & $\begin{array}{l}\text { Electricity production is measured at } \\
\text { the terminals of all alternator sets in } \\
\text { a station. In addition to hydropower, } \\
\text { coal, oil, gas, and nuclear power } \\
\text { generation, it covers generation by } \\
\text { geothermal, solar, wind, and tide and } \\
\text { wave energy, as well as that from } \\
\text { combustible renewables and waste. } \\
\text { Production includes the output of } \\
\text { electricity plants that are designed to } \\
\text { produce electricity only, as well as } \\
\text { that of combined heat and power } \\
\text { plants. Sources of electricity refer to } \\
\text { the inputs used to generate }\end{array}$ & $\begin{array}{l}\text { Canning (1998), United } \\
\text { Nations }\end{array}$ \\
\hline
\end{tabular}




\section{APPENDIX B (continued)}

\begin{tabular}{|c|c|c|}
\hline Variable & Definition and construction & Source \\
\hline & $\begin{array}{l}\text { electricity: hydropower, coal, oil, gas, } \\
\text { and nuclear power. Hydropower refers } \\
\text { to electricity produced by } \\
\text { hydroelectric power plants, oil refers } \\
\text { to crude oil and petroleum products, } \\
\text { gas refers to natural gas but excludes } \\
\text { natural gas liquids, and nuclear refers } \\
\text { to electricity produced by nuclear } \\
\text { power plants. Data are presents as } \\
\text { megawatts per } 1000 \text { people. }\end{array}$ & \\
\hline Paved roads & $\begin{array}{l}\text { Paved roads are roads that have been } \\
\text { sealed with asphalt or similar road- } \\
\text { building materials. Data are presented } \\
\text { in kilometers per } 1,000 \text { people. }\end{array}$ & $\begin{array}{l}\text { Canning (1998), } \\
\text { International Road } \\
\text { Federation }\end{array}$ \\
\hline $\begin{array}{l}\text { Imported computers per } \\
\text { worker }\end{array}$ & $\begin{array}{l}\text { Computer imports in US\$ per worker. } \\
\text { Computers are defined as imports of } \\
\text { assembled computers, as well as } \\
\text { imports of key components, such as } \\
\text { central processing units, memory } \\
\text { chips, storage devices, and peripherals. }\end{array}$ & $\begin{array}{l}\text { Caselli and Coleman } \\
(2001)\end{array}$ \\
\hline $\begin{array}{l}\text { Government } \\
\text { Government consumption } \\
\text { (percent GDP) }\end{array}$ & $\begin{array}{l}\text { The ratio of government consumption } \\
\text { to GDP. }\end{array}$ & $\begin{array}{l}\text { Summers and Heston } \\
\text { (1991); World Bank (2000) }\end{array}$ \\
\hline
\end{tabular}




\section{REFERENCES}

Acemoglu, D., and F. Zilibotti. 2001. "Productivity Differences." Quarterly Journal of Economics 116(2): 563-606.

Alonso-Borrego, C., and M. Arellano. 1996. "Symmetrically Normalised Instrumental Variable Estimation Using Panel Data." Working paper 9612. Madrid: Centro de Estudios Monetarios y Financieros (CEMFI).

Arellano, M., and S. Bond. 1991. "Some Tests of Specification for Panel Data: Monte Carlo Evidence and an Application to Employment Equations." Review of Economic Studies 58(2): 277-97.

Arellano, M., and O. Bover. 1995. "Another Look at the InstrumentalVariable Estimation of Error-Components Models.” Journal of Econometrics 68(1): 29-52.

Attanasio, O. P., L. Picci, and A. Scorcu. 2000. "Saving, Growth, and Investment: A Macroeconomic Analysis Using a Panel of Countries." Review of Economics and Statistics 82(2): 182-211.

Aziz, J., and R. F. Wescott. 1997. "Policy Complementarities and the Washington Consensus." Working paper WP/97/118. Washington: International Monetary Fund.

Barro, R. J. 1990. "Government Spending in a Simple Model of Endogenous Growth." Journal of Political Economy 98 (5, part II): S103-25.

. 1996. "Democracy and Growth." Journal of Economic Growth 1(1): $1-27$.

1999. "Determinants of Economic Growth: Implications of the Global Experience for Chile." Cuadernos de Economía 36(107).

- 2001. "Human Capital and Growth." American Economic Review 91 (May, Papers and Proceedings, 2000): 12-17.

Barro, R. J., and J. W. Lee. 1994. "Sources of Economic Growth." Carnegie-Rochester Series on Public Policy 40:1-57.

. 2000. "International Data on Educational Attainment Updates and Implications." Working paper W7911. Cambridge, Mass.: National Bureau of Economic Growth.

Barro, R. J., and X. Sala-i-Martin. 1992. "Public Finance in Models of Economic Growth.” Review of Economic Studies 59(4): 645-61.

Beaudry, P., and D. Green. 2001. "Population Growth, Technological Adoption and Economic Outcomes: A Theory of Cross-Country Differences for the Information Era.” Working paper W8149. Cambridge, Mass.: National Bureau of Economic Growth.

Beck, T., A. Demirgüç-Kunt, and R. Levine. 2000. "A New Database on Financial Development and Structure." World Bank Economic Review 14(3): 597-605. 
Bennett, H., K. Schmidt-Hebbel, and C. Soto. 2000. "Series de ahorro e ingreso por agente económico.” Estudios de Economía 27(1): 123-70.

Bergoeing, R., P. Kehoe, T. Kehoe, and R. Soto. 2002. "A Decade Lost and Found: Mexico and Chile in the 1980s." Review of Economic Dynamics, 5(1): 166-205.

Bernanke, B., and R. Gurkaynak. 2001. "Is Growth Exogenous? Taking Mankiw, Romer, and Weil Seriously." Working paper W8365. Cambridge, Mass.: National Bureau of Economic Growth.

Blomstrom, M., R. E. Lipsey, and M. Zejan. 1996. "Is Fixed Investment the Key to Economic Growth?" Quarterly Journal of Economics 111(1): 269-76.

Blundell, R., and S. Bond. 1997. "Initial Conditions and Moment Restrictions in Dynamic Panel Data Models." Discussion paper in economics 97/07. London: University College.

Bosworth, B., R. Dornbusch, and R. Labán. 1994. The Chilean Economy: Policy Lessons and Challenges. Washington: Brookings Institution.

Braun, J., and M. Braun. 1999. "Crecimiento potencial: el caso de Chile." Cuadernos de Economía 36(107): 479-517.

Calderón, C., W. Easterly, and L. Servén. 2001. "Infrastructure and Growth in Latin America." Washington: World Bank. Unpublished paper.

Canning, D. 1998. “A Database of World Stocks of Infrastructure.” World Bank Economic Review 12(3): 529-47.

Caselli, F., and J. Coleman. 2001. "Cross-Country Technology Diffusion: The Case of Computers." American Economic Review 91 (May, Papers and Proceedings, 2000): 328-35.

Central Bank of Chile. 2001. Indicadores económicos y sociales, 1960-2000. Santiago.

Chumacero, R., and R. Fuentes. 2001. "On the Determinants of the Chilean Economic Growth." Santiago: Central Bank of Chile. Unpublished paper.

Coeymans, J. E. 1999. "Ciclos y crecimiento sostenible a mediano plazo en la economía chilena.” Cuadernos de Economía 36(107): 545-96.

Collins, S. M., and B. Bosworth. 1996. "Economic Growth in East Asia: Accumulation versus Assimilation." Brookings Papers on Economic Activity 1996(2): 135-91.

Contreras, G., and P. García. 2002. "Estimating Gaps and Trends for the Chilean Economy." Santiago: Central Bank of Chile. Unpublished paper.

Corbo, V., R. Lüders, and P. Spiller. 1997. "The Foundations of Successful Economic Reforms: The Case of Chile." Universidad Católica de Chile. Unpublished paper. 
De Gregorio, J. 1997. "Crecimiento potencial en Chile: una síntesis.” In Análisis empírico del crecimiento en Chile, edited by F. Morandé and R. Vergara. Santiago: CEP/ILADES.

De Gregorio, J., and J. W. Lee. 1999. "Economic Growth in Latin America: Sources and Prospects." Working paper 66. University of Chile, Centro de Economía Aplicada.

De Soto, H., E. Ghersi, and M. Ghibellini. 1986. El otro sendero. El Barranco, Peru: Instituto Libertad y Democracia.

Djankov, S., and others. 2000. "The Regulation of Entry." Working paper W7892. Cambridge, Mass.: National Bureau of Economic Growth.

Dollar, D., and C. Burnside. 2000. "Aid, Policies, and Growth." American Economic Review 90(4): 847-68.

Easterly, W., N. Loayza, and P. Montiel. 1997. "Has Latin America's Post-Reform Growth Been Disappointing?" Journal of International Economics 43: 287-311.

Fatás, A. 2001. “The Effects of Business Cycles on Growth.” INSEAD. Unpublished paper.

Gallego, F., F. Morandé, and R. Soto. 2001. "Ahorro y consumo de bienes durables en el ciclo económico: ¿consumismo, frugalidad, racionalidad?" In Análisis empírico del ahorro en Chile, edited by F. Morandé and R. Vergara. Santiago: Central Bank of Chile.

Griliches, Z., and J. Hausman. 1986. "Errors in Variables in Panel Data." Journal of Econometrics 31(1): 93-118.

Hanushek, E., and Kimko. 2000. "Schooling, Labor-Force Quality, and the Growth of Nations." American Economic Review 90(5): 1184-208.

Hirschman, A. O. 1958. The Strategy of Economic Development. Yale University Press,

Holtz-Eakin, D., W. Newey, and H. S. Rosen. 1998. "Estimating Vector Autoregressions with Panel Data." Econometrica 56:1371-95.

International Currency Analysis, Inc. Various years. World Currency Yearbook. Brooklyn, NY.

Jadresic, E., and R. Zahler. 2000. "Chile's Rapid Growth in the 1990s: Good Policies, Good Luck, or Political Change?” Working paper 153. Washington: International Monetary Fund.

Kaufmann, D., A. Kraay, and P. Zoido-Lobatón. 1999a. "Aggregating Governance Indicators.” Policy research working paper 2195. Washington: World Bank.

_. 1999b. "Governance Matters." Policy research working paper 2196. Washington: World Bank. 
Keller, W. 2001. "International Technology Diffusion.” Working paper W8573. Cambridge, Mass.: National Bureau of Economic Growth.

Knack, S., and P. Keefer. 1995. "Institutions and Economic Performance: Cross-Country Tests Using Alternative Institutional Measures." Economic and Politics 7(3): 207-27.

Lefort, F. 1997. "Crecimiento económico en Chile: evidencia de panel." In Análisis empírico del crecimiento en Chile, edited by F. Morandé and R. Vergara. Santiago: CEP/ILADES.

Levine, R., and D. Renelt. 1992. "A Sensitivity Analysis of Cross-Country Growth Regressions." American Economic Review 82(4): 942-63.

Loayza, N. 1996. "The Economics of the Informal Sector: A Simple Model and Some Empirical Evidence from Latin America." CarnegieRochester Conference Series on Public Policy 45: 129-62.

Mankiw, N. G. 1995. "Growth of Nations." Brookings Papers on Economic Activity 1995(1): 275-329.

Marfán, M., and L. Bosworth. 1994. "Saving, Investment, and Growth." in The Chilean Economy: Policy Lessons and Challenges, edited by R. Dornbusch and R. Labán. Washington: Brookings Institution.

Marshall, M. G., and K. Jaggers. 2000. "Polity IV Project-Political Regime Characteristics and Transitions, 1800-1999: Dataset Users Manual." University of Maryland at College Park. Mimeographed.

Mauro, P. 1995. "Corruption and Growth." Quarterly Journal of Economics 110(3): 681-712.

Meller, P., R. O’Ryan, and A. Solimano. 1996. "Growth, Equity and the Environment in Chile: Issues and Evidence." World Development 24(2): 255-72.

Ortiz, C. H. 2001. "Economic Structure, Long-Run Growth and International Income Differentials." Universidad del Valle. Cali, Colombia. Mimeographed.

Perry, G., and D. Leipziger, eds. 1999. Chile: Recent Policy Lessons and Emerging Challenges. Washington: World Bank.

Przeworski, A., and F. Limongi. 1993. "Political Regimes and Economic Growth." Journal of Economic Perspectives 7(3): 51-69.

Psacharopoulos, G. 1994. "Returns to Investment in Education: A Global Update." World Development 22(9): 1325-44.

Rojas, P., E. López, and S. Jiménez. 1997. "Determinantes del crecimiento y estimación del producto potencial en Chile: el rol del comercio internacional." In Análisis empírico del crecimiento en Chile, edited by F. Morandé and R. Vergara. Santiago: CEP/ILADES. 
Roldós, J. 1997. "El crecimiento del producto potencial en mercados emergentes: el caso de Chile." In Análisis empírico del crecimiento en Chile, edited by F. Morandé and R. Vergara. Santiago: CEP/ILADES.

Romer, P. 1992. "Two Strategies for Economic Development: Using Ideas and Producing Ideas." In The World Bank Annual Conference on Economic Development. Washington: World Bank.

Schmidt-Hebbel, K. 1999. "Chile's Takeoff: Facts, Challenges, Lessons." In Chile: Recent Policy Lessons and Emerging Challenges, edited by G. Perry and D. Leipziger. Washington: World Bank.

Solimano, A. 1999. "The Chilean Economy in the 1990s: On a 'Golden Age' and Beyond.” In After Neoliberalism: What Next for Latin America? edited by L. Taylor. Ann Arbor: University of Michigan Press.

Summers, R., and A. Heston. 1991. "The Penn World Table (Mark 5): An Expanded Set of International Comparisons, 1950-1988." Quarterly Journal of Economics 106(2): 327-68.

TIMSS. 2000. The TIMSS 1999 International Database. Boston University.

Turnovsky, S. 2000. "Growth in an Open Economy: Some Recent Developments." University of Washington. Unpublished paper.

Wood, A. 1988. "Global Trends in Real Exchange Rates, 1960 to 1984." Discussion paper 35. Washington: World Bank.

World Bank. 1997. World Development Indicators, Washington. . 2000. World Development Indicators. Washington.

Young, A. 1989. Hong Kong and the Art of Landing on One's Feet: A Case Study of a Structurally Flexible Economy. Ph.D. dissertation, Tufts University, Fletcher School. 
